\title{
O gênero Copaifera (Leguminosae - Caesalpinioideae) NA AMAZÔNIA BRASILEIRA
}

\author{
Regina C. V. Martins-da-Silva ${ }^{1,4}$, Jorge Fontella Pereira ${ }^{2}$ \\ \& Haroldo Cavalcante de Lima
}

\begin{abstract}
Resumo
(O gênero Copaifera (Leguminosae - Caesalpinioideae) na Amazônia brasileira) O gênero Copaifera está presente na África (4 spp.), América Central (4 spp.), América do Sul (cerca de 37 spp.) e, provavelmente, na Ásia (1 sp.). Foram reconhecidas nove espécies de Copaifera na Amazônia brasileira: Copaifera duckei, $C$. glycycarpa, C. guyanensis, C. martii, C. multijuga, C. paupera, C. piresii, C. pubiflora e C. reticulata, representadas tanto por arbustos ou árvores que chegam a atingir até 40 metros de altura, fornecendo tanto madeira como o óleo-resina, extraído de seu tronco, utilizada na preparação de medicamentos, cosméticos, tintas e revelação de fotografias. O presente trabalho apresenta uma chave para identificação das espécies que ocorrem na Amazônia brasileira, incluindo ilustrações, descrições e comentários sobre morfologia e taxonomia. Palavras-chave: Copaíba, medicinal, óleo-resina, taxonomia, Cesalpiniaceae.
\end{abstract}

\section{Abstract}

(The genus Copaifera (Leguminosae - Caesalpinioideae) in Brazilian Amazonian) Copaifera occurs in Africa (4 spp.), Central America (4 spp.), South America (about $37 \mathrm{spp}$.) and probably in Asia (1 sp.). Nine species were recognized within the Brazilian Amazon: Copaifera duckei, C. glycycarpa, C. guyanensis, $C$. martii, C. multijuga, C. paupera, C. piresii, C. pubiflora e C. reticulata. Their habit varies between shrubby and tree-like, with some species forming $40 \mathrm{~m}$ tall trees. Copaifera is economically important as a timber source, and increasingly as the source of an oleoresin used as a component of medicines, cosmetics, ink and film-development. The present treatment includes an identification key for the species, illustrations, descriptions and comments regarding the morphology, taxonomy and distribution of the species treated.

Key words: Copaíba, medicinal, oleoresin, taxonomy, Caesalpiniaceae.

\section{INTRODUÇÃo}

As espécies conhecidas popularmente como 'copaíba', 'copaibeiras', 'pau d'óleo', entre outros nomes pertencem ao gênero Copaifera (Leguminosae-Caesalpinioideae), que ocorre na Âfrica (4 spp.), nas Américas Central (4 spp.) e do Sul (cerca de 37 spp.) e, provavelmente, na Ásia (1 sp.) (Hayne 1827; Bentham 1870; Léonard 1949, 1950; Dwyer 1951; De Wit 1953; Enrech et al. 1983; Poveda et al. 1989; Hou 1994; Martins-da-Silva 2006). Considerou-se como ocorrência provável na Ásia, por haver dúvidas quanto à transferência de Pseudosindora palustris Symington para Copaifera, visto que o próprio autor da espécie (Symington 1942), ao descrevê-la, fez referência à ausência de canais intercelulares no tronco e esse é um caráter presente nas espécies do gênero Copaifera. A ausência desse caráter na referida espécie foi também confirmada por Quirk (1983) ao estudar as madeiras da Ásia.

As espécies desse gênero podem ser arbustos ou árvores que chegam a atingir até cerca de $40 \mathrm{~m}$ de altura e são fornecedoras de madeira e óleo-resina, dois produtos extraídos de seu tronco e explorados em níveis comercial e industrial. A madeira é utilizada na produção de compensados e o óleo-resina é empregado na medicina popular como antiinflamatório e antibactericida, sendo seu uso também conhecido como combustível na iluminação doméstica rudimentar (Corrêa 1931; Alencar 1982; Berg 1993; Siqueira 1996; Shanley et al. 2005).

Artigo recebido em 09/2006. Aceito para publicação em 09/2007.

${ }^{1}$ Embrapa Amazônia Oriental, Tv. Enéas Pinheido s/n, Bairro Marco, 66095-100, Belém, PA, Brasil.

${ }^{2}$ Museu Nacional do Rio de Janeiro/UFRJ; Bolsista I-B do CNPq

${ }^{3}$ Instituto de Pesquisa Jardim Botânico do Rio de Janeiro. R. Pacheco Leão 915, 22460-030, Rio de Janeiro, RJ, Brazil.

${ }^{4}$ Autor para correspondência: regina@cpatu.embrapa.br ou rcvms@supridados.com.br 
Veiga Junior \& Pinto (2002) comentaram que apesar da extensa literatura sobre os óleosresina de Copaifera, poucos são os artigos nos quais é encontrada a identificação botânica da espécie estudada. Assim, se torna impossível proceder a uma comparação entre os diversos resultados, visto que os dados químicos encontrados em uma espécie podem ser completamente diferentes em outra, como se pode verificar nos trabalhos realizados por Maia et al. (2001) e Cascon \& Gilbert (2000), que demonstraram existir diferenças nas características químicas do óleo proveniente de diferentes espécies e até mesmo no âmbito de uma mesma espécie. Segundo Cascon \& Gilbert (2000), é necessário, antes, se conhecer a variabilidade da composição química inter- e intraespecífica das Copaifera para, só depois, utilizar o óleo-resina como matéria prima para medicamentos e cosméticos. Segundo Langenhein (2003), a variação na composição química do óleo-resina de Copaifera pode influenciar a ação farmacológica e a toxidez dos produtos que o utilizam em suas composições, podendo comprometer o controle de qualidade.

Apesar dos vários estudos sobre a taxonomia do gênero Copaifera realizados ao longo de quase três séculos, ainda existiam dificuldades para reconhecer as espécies que ocorrem na Amazônia brasileira devido à carência de informações de campo sobre a variação de características morfológicas e a ausência de ilustrações demonstrativas dos caracteres-chave. Assim, essa dificuldade tornou-se barreira para o avanço dos estudos de caracterização química de tais espécies e, conseqüentemente, melhor aproveitamento industrial da madeira e óleo-resina, e no mais o manejo adequado desses recursos.

Diante da necessidade de se conhecer as espécies de Copaifera que estão fornecendo óleo-resina na Amazônia, procedeu-se ao estudo taxonômico desse gênero na referida região.

O objetivo deste trabalho é apresentar o tratamento taxonômico das nove espécies de Copaifera que ocorrem na Amazônia brasileira acompanhado de uma chave de identificação, descrições, ilustrações e comentários sobre morfologia e taxonomia.

\section{Material e Métodos}

A Amazônia brasileira ocupa integralmente cinco estados, ou seja, Acre, Amapá, Amazonas, Pará e Roraima, bem como parte dos estados do Maranhão, Mato Grosso, Rondônia e de Tocantins (MMA 2004). Abrange uma área de aproximadamente quatro milhões de $\mathrm{km}^{2}$, com temperatura média em torno de $25^{\circ} \mathrm{C}$, com chuvas torrenciais bem distribuídas ao longo do ano (MMA 2004). A diversidade geológica é bastante variada, aliada ao relevo diferenciado e influência das altas temperaturas, bem como altos níveis de precipitação, resultando na formação das mais variadas classes de solo. A vegetação característica é a Floresta Ombrófila Densa que apresenta variações, principalmente ao longo do rio Amazonas e seus principais afluentes. Está situada na zona neotropical e abriga a maior bacia hidrográfica do planeta, escoando 1/5 da água doce da Terra. Seus rios são classificados de acordo com a cor de suas águas e os sedimentos que transportam (Arruda 2001; MMA 2004).

Foram analisados materiais coletados nos diversos estados da Amazônia, bem como exemplares procedentes dos seguintes herbários: CAY, COL, F, GUA, HAMAB, HB, HRCB, IAC, IAN, INPA, IPA, K, L, MG, R, RB, SGO, SP, SPF, TEPB, U, UB, UEC, UFMT e VEN (acrônimos de acordo com Holmgren \& Holmgren 1998). Analisou-se, ainda, material de herbários não indexados, isto é, da Universidade Federal do Acre (HPZ), Universidade Federal do Amazonas (HUAM) e da Orsa Florestal (JARI). Além disso, foram examinadas fotografias de tipos depositadas nos herbários F, GH, IAN e RB, bem como imagens digitais dos herbários A, B, G, FHO, GH, K, M, MO, NY, OXF, P, US, Z e WIS. O bioma Amazônia foi delimitado segundo MMA (2004), porém para habitat seguiu-se Pires \& Prance (1985). A terminologia na descrição dos táxons foi adotada segundo Lawrence (1951), Rizzini (1977), Stearn (1998), Harris \& Harris (2001) e Hickey \& King (2003). 
Folíolos foram diafanizados segundo a técnica de Johansen (1940) para contagem de aréolas que foi realizada com auxílio de microscópio ótico, com quadrado de $1 \mathrm{~mm}^{2}$ acoplado à lente. Foi conferido o número de aréolas por $\mathrm{mm}^{2}$ com 10 repetições em cada folíolo, sendo utilizados 3-5 folíolos por espécie.

Considerou-se venação laxa, quando a média do número de aréolas por $\mathrm{mm}^{2}$ na superfície dos folíolos esteve compreendida entre 8-12 (Tab. 1) e, venação congesta, com média acima de 15 aréolas por $\mathrm{mm}^{2}$ (Tab. 1).

\section{Resultados e Discussão}

Copaifera L., Sp. Pl. ed.2: 557. 1762, nom. cons.

Espécie tipo: Copaifera officinalis (Jacq.) L. (Copaiva officinalis Jacq.).

Arbustos ou árvores; tronco cilíndrico, anéis circulares ao longo do tronco. Canais secretores intercelulares, axiais, dispostos em faixas de parênquima axial marginal, concêntricas, no tronco. Folhas alternas, paripinadas; folíolos 2-12 pares, opostos, alternos ou subopostos, inteiros, podendo apresentar pontuações translúcidas; venação pinada, broquidódromo, arcos formando-se próximo à nervura marginal, nervura intersecundárias presentes, reticulação laxa ou congesta, conspícua ou inconspícua, 1-2(3) glândulas no $1 / 4$ basal da nervura marginal; estípulas interpeciolares geralmente caducas. Inflorescência em panículas, alternas, botões florais protegidos por duas bractéolas e uma bráctea caducas, internamente glabras, externamente glabras, glabrescentes ou pubescentes. Flores monoclamídias (pétalas ausentes), sésseis ou subsésseis, alvas. Cálice tetrâmero formando tubo curto, conato a um pequeno disco; sépalas variando em largura:
Tabela 1 - Valores mínimo, médio (em negrito) e máximo do número de aréolas por $\mathrm{mm}^{2}$ na superfície dos folíolos das espécies de Copaifera estudadas.

\begin{tabular}{cc}
\hline Espécie & No. aréolas $/ \mathbf{m m}^{\mathbf{2}}$ \\
\hline C. duckei & $5-\mathbf{8 , 7}-11$ \\
C. glycycarpa & $16-\mathbf{2 1 , 4 - 2 9}$ \\
C. guyanesis & $6-\mathbf{8 , 2}-11$ \\
C. martii & $13-\mathbf{1 6 , 8}-22$ \\
C. multijuga & $18-\mathbf{2 9 , 5}-41$ \\
C. paupera & $15-\mathbf{2 1 , 7}-28$ \\
C. piresii & $9-\mathbf{1 1 , 4}-14$ \\
C. pubiflora & $8-\mathbf{1 5 , 2}-21$ \\
C. reticulata & $6-\mathbf{9 , 3}-12$ \\
\hline
\end{tabular}

uma mais larga, mais côncava oposta a outra mais estreita, quase reta, intercaladas por duas médias, similares, ligeiramente côncavas, hirsutas internamente, pubescentes, glabrescentes ou glabras externamente. Androceu com 10 estames livres, de dois tamanhos, intercalados na margem do disco; filetes glabros; anteras oblongas, apiculadas ou não no ápice, glabras, dorsifixas, rimosas. Gineceu com ovário comprimido lateralmente, preso no centro do disco, estipitado ou séssil, totalmente hirsuto ou apenas na nervura principal, sutura do carpelo, ápice e base; óvulos 2, alongados, superpostos; estilete filiforme; estigma terminal, globoso, papiloso. Frutos, legumes estipitados, obliquamente elípticos ou falcado-ovados, sub-orbiculares ou obovados, geralmente comprimidos lateralmente, em geral apiculados; semente 1 (2), pêndula, oblongo-globosa, nigrescente, coberta por arilo branco ou amarelo, endosperma ausente.

\section{Chave para identificação das espécies de Copaifera ocorrentes na Amazônia brasileira}

1. Venação foliolar congesta (média de aréolas $/ \mathrm{mm}^{2}$ na superfície dos folíolos superior a 15) e inconspícua na face adaxial.

2. Folíolos 6-12 pares; ovário totalmente hirsuto.

3. Folíolos opostos, retos, simétricos, ovário séssil, frutos globosos ......2. C. glycycarpa

3'. Folíolos alternos, falcados, assimétricos, ovário estipitado, frutos comprimidos lateralmente 5. C. multijuga 
2'. Folíolos até 5 pares; ovário hirsuto na sutura do carpelo e ao longo da nervura principal.

4. Folíolos com comprimento maior do que o dobro da largura, alternos, arilo amarelo ....

6. C. paupera

4'. Folíolos com comprimento menor do que o dobro da largura, opostos ou subopostos, arilo branco.

5. Folíolos opostos, 3-4 pares, margens ligeiramente revolutas, sépalas glabrescentes ou glabras externamente 4. C. martii

5'. Folíolos subopostos, (1)2-3 pares, margens não revolutas, sépalas pubescentes externamente

8. C. pubiflora

1'. Venação foliolar laxa (média de aréolas $/ \mathrm{mm}^{2}$ na superfície dos folíolos inferior a 12) e conspícua na face adaxial.

6. Folíolos 0,9-2,8 cm compr., 4-7 pares, peciólulos 0,4-1 mm compr.

7. C. piresii

6'. Folíolos maiores do que $3 \mathrm{~cm}$ compr., (2)3-6 pares, peciólulos 0,2-0,8 cm compr.

7. Folíolos opostos, retos, (2)3-4 pares, sépalas pubescentes externamente, frutos com $3-5 \mathrm{~cm}$ de comprimento 3. C. guyanensis

7'. Folíolos alternos ou subopostos, subfalcados ou falcados, 3-6 pares, sépalas glabras ou glabrescentes externamente, frutos com 2,3-4 cm compr.

8. Folíolos 4-6 pares, raque foliar 6-12,3 cm compr., pecíolo e peciólulo pubescentes ou glabrescentes, nervura central (face abaxial) pubescente ou glabrescente, sépalas glabrescentes ou glabras externamente ........................ 9. C. reticulata

8'. Folíolos 3-4 pares, raque foliar 2,5-7,3 cm compr., pecíolo e peciólulo glabros ou glabrescentes, nervura central (face abaxial) glabra, sépalas glabras externamente

1. C. duckei

1. Copaifera duckei Dwyer, Brittonia 7 (3): 163-164. 1951. Tipo: BRASIL. PARÁ: Belém do Pará, 10.XI.1922, fl., A. Ducke 16875 (Lectótipo US 1441916!, aqui designado; duplicatas do lectótipo K!, RB!). $\quad$ Fig. 1 a-f

Árvore (15)20-35(45) m alt. e (25)35-95 cm DAP; ritidoma estriado, cinza-rosado. Folhas com 3-4 pares de folíolos, pecíolo e raque glabros ou glabrescentes, pecíolos $0,7-$ $2 \mathrm{~cm}$ compr., raque 2,5-7,3 cm compr.; estípulas interpeciolares caducas. Folíolos alternos ou subopostos, coriáceos, oblongo-ovados, subfalcados, assimétricos, base obtusa subequilátera, raramente cuneada, ápice curto acuminado com ou sem apículo, os distais 3,4-6,7 $\times 1,4-3,3 \mathrm{~cm}$, proximais $2,4-4,7 \times 1,3-3,7 \mathrm{~cm} \mathrm{e}$ medianos 3,2-5,6 × 1,5-2,9 cm, faces abaxial e adaxial glabras, margens retas; nervura central adaxial proeminente, pubescente ou glabrescente, abaxial glabra; venação laxa (média 8,7 aréolas/ $\mathrm{mm}^{2}$ ), conspícua na face adaxial; pontuações translúcidas quase sempre presentes; peciólulos glabros ou glabrescentes, ca. 0,2 cm compr.
Inflorescências 5,5-13 cm compr.; bráctea 1,4-1,9 × 1,2-1,7 mm, faces abaxial e adaxial glabras, tricomas nas margens; bractéolas 1$1,3 \times 0,7-0,9 \mathrm{~mm}$, faces abaxial e adaxial glabras, tricomas nas margens. Flores subsésseis; sépalas externamente glabras, a mais larga 3,24,4 $\times 2-3,1 \mathrm{~mm}$, as médias $3,2-4,4 \times 1,2-2 \mathrm{~mm}$ e a mais estreita $3,2-4,4 \times 0,8-1,1 \mathrm{~mm}$; anteras 1,3-2,2 $\times 0,7-1 \mathrm{~mm}$; gineceu 3,7-4,1 mm compr., ovário oblongo-elíptico, estipitado, 1,7-1,9×1$1,3 \mathrm{~mm}$, hirsuto na sutura e nervura principal do carpelo, no ápice e na base; estilete 2-2,2 mm compr. Frutos obovados, sub-orbiculares, algumas vezes oblíquos, $3-4 \times 2,2-3,2 \mathrm{~cm}$, base falcada ou subfalcada, ápice arredondado ou truncado; semente 1,4-1,8 $\times 1-1,3 \mathrm{~cm}$, arilo amarelo.

Material selecionado: BRASIL. MARANHÃO: Maracassumé River Region, 20.IX.1932, Fróes 1926 (US, A, F, K, NY); Santa Luzia, Arrastão do Cajueiro, 10.VII.2002, M. L. B. Jesus 25 (IAN). PARÁ: Belém, Mosqueiro, propriedade Mari-mari, ramal Sapucaia, 25.IV.2002, fr., R. C. V.Martins-da-Silva etal. 76(IAN); Castanhal, colônia Três de Outubro, 23.I.1953, fl., J. M. Pires \& N. T. Silva 4453 (IAN, INPA, IPA, K, R). 

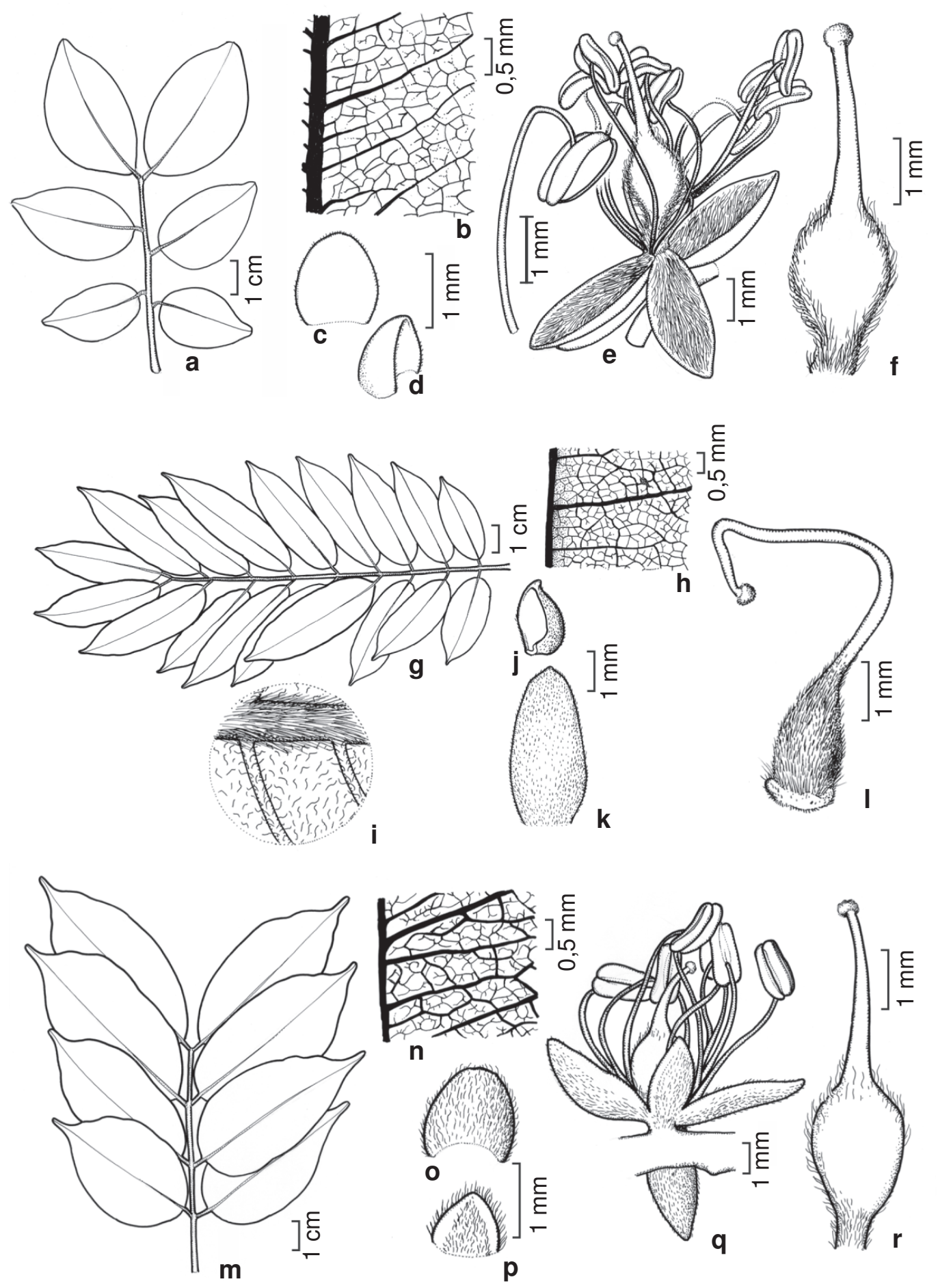

Figura 1 - a-f. Copaifera duckei - a. folha; b. detalhe do folíolo evidenciando venação laxa; c. bráctea. d. bractéola. e. flor; f. gineceu. g-l. C. glycycarpa - g. folha; h. detalhe do folíolo evidenciando venação congesta; i. detalhe do folíolo evidenciando tricomas na face abaxial da lâmina; j. bractéola; k. bráctea; l. gineceu. m-r. C. guyanensis - m. folha. n. detalhe do folíolo evidenciando venação laxa; o. bráctea; p. bractéola; q. flor; r. gineceu. (a Freitas 180; b Pires 4453; c-f Freitas 151; g-i Martins-da-Silva 190; j-1 Ducke s.n. (RB20218); m, o-p Rosa 522; n Damião 3097; q-r Spruce s.n. (RB5159)) 
Ocorre apenas no Brasil, no nordeste da Amazônia brasileira; foi encontrada desde o nordeste do estado do Pará até o noroeste do Maranhão (Fig. 4). Habita as matas de terra firme.

Dwyer (1951), ao descrever C. duckei, citou como tipo uma duplicata do material Ducke s.n. (RB 16875) depositada no herbário US, além de outras coletas adicionais procedentes da Bahia, Ceará e Maranhão. Posteriormente, Ducke (1959) ao descrever C. cearensis, validando um nome não publicado por J. Huber, reconheceu como pertencendo a esta espécie parte do material incluído por Dwyer (1951) em C. duckei. O referido autor, discordando ainda da proposição de Dwyer, colocou em dúvida a validade de $C$. duckei, aventando a possibilidade de ser uma mera forma de $C$. reticulata.

Sobre a coleta Riedel 686, oriunda da Bahia e citada por Dwyer como parátipo de C. duckei, verificou-se que não pertence a essa espécie, por possuir mais de quatro pares de folíolos, estando incompletamente conhecida.

Dwyer após a descrição de $C$. duckei menciona o material Ducke16875 (US, Type). Com o exame do referido material depositado no Jardim Botânico do Rio de Janeiro, constatou-se que na mesma exsicata, Ducke cita duas datas diferentes de coleta, uma de um exemplar coletado em 10 de novembro de 1922, em flor, e outra de um exemplar coletado em 23 de junho de 1923, em fruto. Quem trabalhou no herbário do Jardim Botânico sabe que inúmeros exemplares coletados por Ducke têm datas diferentes de coleta na mesma exsicata. Porém, as duplicatas que se encontram em (US), foram desmembradas em: 'Sheet' I (US-1441917) com as duas datas acima referidas e 'Sheet' II, (US-1441916), com a data de 23 de junho de 1923, em fruto. Como o Código de Nomenclatura, 2006, Art.8, diz que o holótipo não pode consistir de material coletado em duas datas diferentes, optou-se pela lectotipificação, escolhendo a Sheet II (US1441916), material coletado em fruto, por Ducke, em 23 de junho de 1923.

Copaifera duckei é afim de C. reticulata, da qual difere por possuir três a quatro pares de folíolos oblongo-ovados, raque da folha menor (2,5-7,3 cm compr.), sendo glabra ou glabrescente; geralmente, o pecíolo, peciólulo e nervura central são glabros, entretanto, mais raramente, são glabrescentes, principalmente quando mais jovens; contudo a nervura central é glabra na face abaxial. Brácteas, bractéolas e sépalas externamente são glabras. O retículo formado pela venação na face adaxial dos folíolos, em C. duckei, é mais conspícuo e brilhante, bem como as aréolas são ligeiramente maiores do que em $C$. reticulata, tendo sido encontrada uma média de 8,7 aréolas por $\mathrm{mm}^{2}$ em C. duckei.

O tamanho dos frutos foi considerado por Dwyer (1951) como um dos caracteres para separar as duas espécies, informando que em C. duckei são maiores $(3,3-3,5 \times 2,5-3 \mathrm{~cm})$ do que em $C$. reticulata $(2,7-3,2 \times 2-3 \mathrm{~cm})$, no entanto, foram encontrados, na FLONA do Tapajós (PA), frutos de $C$. reticulata medindo até $3,7 \times 3,5 \mathrm{~cm}$.

2. Copaifera glycycarpa Ducke, Arch. Jard. Bot. Rio de Janeiro 5: 128-129. 1930. Tipo: BRASIL. AMAZONAS: "habitat in silvis non inundatis ad ripas fluminis Curuçá prope oppidum Maués civitatis Amazonas", 17.XII.1927, fl., Ducke s.n (Lectótipo RB 20218!, aqui designado; duplicatas do lectótipo F!, K!, NY!, RB!, U!, US!). Fig. 1 g-1 Árvore (25)30-35 m alt., 46-80 cm DAP; ritidoma estriado, cinza a castanho-avermelhado. Folhas com 8-12 pares de folíolos, pecíolo e raque ferrugíneo-tomentosos, pecíolo 1,3-1,9 cm compr., raque 11,1-19,3 cm compr.; estípulas interpeciolares caducas. Folíolos opostos, coriáceos, oblongo-lanceolados, retos, simétricos, base obtuso-rotunda, ápice agudo-acuminado, apiculado, os distais 4,8-8,2 $\times 1,2-2,7 \mathrm{~cm}$, os proximais $3,2-5,6 \times 1,2-2,5 \mathrm{~cm}$ e os medianos 3,4-7 × 1,6-2,6 cm, faces adaxial glabra ou glabrescente, face abaxial pubescente, margens semi-revolutas, nervura central adaxial impressa glabra, abaxial hirsuta; venação congesta (média 21,4 aréolas $/ \mathrm{mm}^{2}$ ), inconspícua na face adaxial à vista desarmada; pontuações translúcidas imperceptíveis; peciólulos tomentosos, 0,2-0,4 cm compr. Inflorescências 
com 27-33 cm compr., bráctea 4,5-6×3-4 mm, abaxial pubescente, adaxial glabra, tricomas nas margens; bractéolas 2-2,7 ×2,2-2,9 mm, abaxial pubescentes, adaxial glabras, tricomas nas margens. Flores com sépalas externamente tomentosas, ovário oblongo-ovado, séssil, ca. 2,5 $\times 2 \mathrm{~mm}$, totalmente hirsuto; estilete ca. $6 \mathrm{~mm}$ compr. Frutos globosos, elíptico-obovados, 4-4,5 $\times 2,9-4 \mathrm{~cm}$, base ligeiramente cuneada, ápice arredondado; semente oblongo-globosa, ca. 2 $\times 1 \mathrm{~cm}$, arilo amarelo.

Material selecionado: BRASIL. AMAZONAS: Itacoatiara, estrada Torquato Tapajós, km 227, terreno da Mil Madeireira, 8.V.1996, fr., L. F. Coêlho s.n. (INPA 186048); Novo Aripuanã, BR-230, Rodovia Transamazônica a 300km de Humaitá, próx. ao acampamento do DNER, $7^{\circ} 33^{\prime} \mathrm{S}, 60^{\circ} 40 \mathrm{~W}, 24 . \mathrm{IV} .1985$, fr., C.A.C. Ferreira et al. 5734 (INPA). MATOGROSSO: near Tabajara, upper Machado River Region, XIXII.1931, fr., B. A. Krukoff 1497 (F, K). PARÁ: “ad medium flumen Tapajoz loco Quataquara (civitate Pará)", 14.VIII.1923, fr., Ducke s.n. (síntipos RB 17069, U; foto do síntipo RB: F). RONDÔNIA: Itapuã do Oeste, Flona do Jamari, 7.VIII.1987, fr., P. S. Teixeira et al. 272 (INPA); Porto Velho, Campo Experimental daEmbrapa de Porto Velho, $8^{\circ} 48^{\prime}$ 'S, 635 51W, 28.X.2004, fr., R. C. V. Martins-da-Silva et al. 190 (IAN).

Ocorre apenas no Brasil, na região central da Amazônia brasileira e estende-se até a sudoeste e sul dessa região; foi encontrada no sudoeste do Pará, leste do Amazonas e noroeste de Mato Grosso (Fig. 4). Habita as matas de terra firme.

Copaifera glycycarpa destaca-se por apresentar tricomas na face abaxial da lâmina do folíolo, ovário séssil e fruto globoso com apículo rudimentar. Entretanto, devido ao relativamente grande número de folíolos e ao ovário totalmente hirsuto, C. glycycarpa é afim de $C$. multijuga, sendo ambas as únicas, na Amazônia, que possuem o ovário totalmente hirsuto. Porém, C. glycycarpa difere por apresentar folíolos simétricos, retos e opostos, bem como ovário séssil e fruto globoso. A venação dos folíolos em ambas as espécies apresenta-se congesta e inconspícua na face adaxial; entretanto, $C$. glycycarpa difere por possuir em média 21,4 aréolas $/ \mathrm{mm}^{2} \mathrm{e}$ as veias com terminações livres apresentando bifurcações.
A descrição das flores foi complementada pela tradução do Protólogo (Ducke 1930), pois os materiais examinados continham apenas botões florais e ovário.

Dwyer (1951) faz a indicação de Ducke 20218 como um fragmento do cotipo (uma designação antiga para síntipo e outras categorias de Tipos) depositado em (F), porém, Ducke menciona no protólogo de sua nova espécie que os síntipos estão depositados no herbário do Jardim Botânico do Rio de Janeiro, daí a lectotipificação apresentada neste trabalho.

3. Copaifera guyanensis Desf., Mém. Mus. Hist. Paris, 7: 376-377, tab. 13. 1821. Tipo: GUYANE. Indigène dês forêts, croît dans lê voisinage du Rio-Negro - Tipo não localizado.

Fig. $1 \mathrm{~m}-\mathrm{r}$

Árvore grande ou mediana (5-7)10-27,5$30 \mathrm{~m}$ alt. e 30-39,7-50 cm DAP; ritidoma cinza-esbranquiçado a castanho, com estrias longitudinais, superficiais, cerradas. Folhas com (2)3-4 pares de folíolos, pecíolo e raque glabros ou glabrescentes, pecíolo 1,9-4,2 cm compr., raque 5-13,4 cm compr.; estípulas interpeciolares caducas. Folíolos opostos, cartáceos ou coriáceos, oblongo-lanceolados ou ovado-lanceolados, retos, simétricos, base arredondada ou raramente cuneada, equilátera, ápice estreito acuminado e apiculado, os distais $7,5-14,15 \times 2,5-5,8 \mathrm{~cm}$, os proximais $6,2-12,3$ $\times 2,9-5,8 \mathrm{~cm}$ e os medianos $7,3-14 \times 2,3-5,8 \mathrm{~cm}$, faces adaxial e abaxial glabras, margens retas; nervura central adaxial impressa, glabra ou glabrescente, abaxial glabra ou glabrescente; venação laxa (média 8,2 aréolas $/ \mathrm{mm}^{2}$ ), conspícua na face adaxial; pontuações translúcidas distribuídas, preferencialmente, de forma homogênea em toda a lâmina, raramente imperceptíveis; peciólulos glabros ou glabrescentes, $0,4-0,7 \mathrm{~cm}$ compr. Inflorescências $8-18 \mathrm{~cm}$ compr; bráctea 1,4-2,1 ×1,4-2,5mm, face abaxial pubescente, a adaxial glabra, tricomas nas margens; bractéolas, $0,8-1,4 \times 0,7-1,3 \mathrm{~mm}$, abaxial pubescentes, adaxial glabras com tricomas nas margens. Flores sésseis a subsésseis; sépalas externamente pubescentes, a mais larga 3,5-4,7 
$\times 1,4-3 \mathrm{~mm}$, as médias 3,5-4,7×1-2,3 mm e a mais estreita $3,5-4,7 \times 0,8-2 \mathrm{~mm}$; anteras $1,6-$ 2,8 $\times 0,8-1,1 \mathrm{~mm}$; gineceu 4,5-6 mm compr., ovário oblongo-obovado, estipitado, 2,2-2,9×1,4$2,2 \mathrm{~mm}$, hirsuto na sutura e nervura principal do carpelo, no ápice e na base; estilete glabro, 1,8-3 mm compr. Frutos oblongo-obovados, elíptico-obovados ou oblongo-oblíquos, comprimidos lateralmente, $3-5 \times 1,8-3,5 \mathrm{~cm}$, estipitados, base sub-falcada ou falcada, ápice arredondado ou truncado; semente oblongoglobosa, 1,7-2,3 ×1,3-1,4 cm, arilo branco.

Material selecionado: BRASIL. AMAZONAS: rio Negro inferior, XI.1851, fl., R. Spruce s.n. (RB 5159, K); rio Negro, foz do Caiarí, 1.X.1952, fr., R. L. Fróes 28807 (IAN, INPA, R). COLÔMBIA. Rio LoretoYaco, 2.XI.1946, fl. e fr., G. A. Black et al. 46-301 (F, IAN, K); VAUPÉS: rioApaporis (LaLibertad), 23.V.1977, fr., A. Roa 710 (INPA). GUIANA FRANCESA. CAYENNE: Fleuve Oyapock, Crique Sikini, "Gros Saut”, 21.VII.1969, fr., B. Oldeman B2594 (CAY); SAINT-LAURENTDU MARONI: Bords dé la Rivière du Maroni, 1862, fl., M. Melinon, s.n. (R 69717, F). SURINAME. BROKOPONDO: near Kabelstation, Suriname River, 8.XI.1933, fr., J. Lanjouw 1157(IAN, K). PARA: Jodensavanne-Mapannekreek area, Kamp 8, 1962, J. Elburg 9394 (F, WIS); Zanderij I, 1.X.1942, fl., G. Stahel 92 (K, UB, WIS). SARAMACCA: Tottikamp, 19.III.1950, fl., B.B.S. 506 (K). SIPALIWINI: Jacobkondre, Saramacca River, 16.VI.1944, fr., $B$. Maguire 23836 (F, K, RB); Posoegronce, Saramacca River, 29.VI.1944, fl., B. Maguire 24015 (F, K, RB).

Ocorre no Brasil, Colômbia, Guiana Francesa e Suriname. Espécie com ampla distribuição no norte da América do Sul, tendo sido encontrada desde a Guiana Francesa, Suriname e Colômbia, estendendo-se até a região amazônica no Brasil. Na Amazônia brasileira, ocorre nas porções central e ocidental; foi encontrada apenas no estado do Amazonas (Fig. 4). Habita preferencialmente matas de várzea e igapó, mas também pode ocorrer em matas de terra firme e campinarana.

Desfontaines (1821), ao descrever $C$. guyanensis não designou o tipo, apenas fez referência de que era uma árvore nativa das florestas da Guiana Francesa, crescia nas cercanias do rio Negro, e que, no herbário do Museu, havia alguns ramos com flores. Como trabalhava no herbário de Paris, supõe-se que estava se referindo a esse herbário; porém, a mesma não foi localizada. Dwyer (1954) comentou que ficou desapontado por não conseguir localizar o tipo no herbário de Paris, mas sugeriu que o mesmo poderia estar no herbário de Florence, já que grande parte das coletas de Desfontaines encontra-se nesse herbário. Diante da impossibilidade de localizar o tipo, a determinação do material foi baseada no protólogo de C. guyanensis (descrição e estampa) e também em outros materiais determinados por Ducke que serviram para comparação.

Dwyer (1951) indicou C. beyrichii Hayne e $C$. bijuga Hayne como sinônimos de $C$. guyanensis, porém, C. beyrichii é uma Connaraceae e de acordo com Forero (1983) é sinônimo de Connarus beyrichii Planchon. Examinando o tipo de C. bijuga, a diagnose e a prancha contidas na obra princeps, não se pode concordar com a sinonímia proposta por Dwyer (1951) quanto à $C$. bijuga, pois a mesma foi descrita como apresentando duas jugas, incurvas e assimétricas, discordando dessa forma de C. guyanensis.

Copaifera guyanensis é bem definida morfologicamente, por exibir três a quatro pares de folíolos, raramente dois, opostos, relativamente grandes $(6,2-14,15 \times 2,3-5,8 \mathrm{~cm})$, oblongolanceolados ou oblongo-ovados, retos, com ápices acuminados que podem ser longos ou mais curtos e lâmina simétrica. A consistência dos folíolos em C. guyanensis varia, pode ser cartácea ou coriácea, o ápice dos folíolos e a base também podem variar de base arredondada a ligeiramente cuneada, embora esta última mais rara e os ápices estreitos acuminados.

Discorda-se das identificações de Dwyer (1951) para as coletas Curran 53 (G, US) e 103 (G, US, Y), procedentes da Bahia. Ao examinar as fotos destes exemplares, verificase que possuem folíolos falcados, devendo provavelmente se tratar de $C$. lucens Dwyer. Lewis (1987) citou C. guyanensis ocorrendo na Bahia, porém explicou que essa informação foi extraída da revisão de Dwyer (1951). 
As coletas Lisboa et al. 1967 (MG 96337) e Silva et al. 937 (MG 78478), procedentes de Carauari (AM), apresentam quatro pares de folíolos cuja forma e filotaxia assemelham-se à $C$. guyanensis; porém, com tricomas na face abaxial da lâmina. Como as referidas amostras encontram-se estéreis e esse caráter não foi detectado nos demais materiais analisados da espécie, preferiu-se não incluí-las, neste momento, em $C$. guyanensis, até que se obtenha material fértil que possa dirimir esta dúvida.

4. Copaifera martii Hayne, Getreue Darstell. Gew. 10: tab. 15. 1827. Tipo: BRASIL. Wächst in Brasilien in den Wäldern der Provinz Para am Amazonenflusse, s.d. (1819?), fl., Martius s.n. (Lectótipo M!, aqui designado; duplicata do lectótipo L!).

Fig. 2 a-f

Arbusto ou árvore $(0,8) 2-40(48) \mathrm{m}$ alt. e 4-90(101) cm DAP; ritidoma estriado, cinzaavermelhado a cinza-acastanhado. Folhas com 3-4 pares de folíolos, pecíolo e raque glabrescente, pecíolo 1-2,5 cm compr., raque 2,5-6,2 cm compr.; estípulas interpeciolares caducas. Folíolos opostos, coriáceos, oblongo-ovados, oblongo-elípticos, orbiculares, retos a subfalcados, assimétricos, base obtusa subequilátera, ápice arredondado ou acuminado, raro apiculado, os distais 3,7-9,3 $\times 1,9-4,9 \mathrm{~cm}$, os proximais $3,4-8,1 \times 1,9-4,1 \mathrm{~cm}$ e os medianos 4-9,1 $\times 2,0-4,6 \mathrm{~cm}$, faces adaxial e abaxial glabras, margens semi-revolutas na região basal; nervura central adaxial impressa, glabra, abaxial glabra ou glabrescente; venação congesta (média 16,8 aréolas $/ \mathrm{mm}^{2}$ ), inconspícua adaxial; pontuações translúcidas quase sempre ausentes; peciólulos glabros ou glabrescentes, $0,2-0,3 \mathrm{~cm}$ compr. Inflorescências $7-15 \mathrm{~cm}$ compr., bráctea 1,7-3×1,3-2,5 mm, face abaxial glabrescente, face adaxial glabra, tricomas nas margens; bractéolas 1,2-2,4×0,8-1,8 mm, abaxial glabrescente, adaxial glabras, tricomas nas margens. Flores sésseis; sépalas externamente glabras ou glabrescentes, podendo apresentar raros tricomas na base e no ápice, a mais larga $2,8-3,7 \times 1,8-2,7 \mathrm{~mm}$, as médias $2,8-3,7 \times 1,3-$ $2,4 \mathrm{~mm}$ e a mais estreita $2,8-3,7 \times 0,9-1,4 \mathrm{~mm}$; anteras 1,2-1,6×0,6-0,9 mm; gineceu $3,4-4,9 \mathrm{~mm}$ compr., ovário oblongo-elíptico a suborbicular, estipitado, 1,6-2,2 ×1,1-1,9 mm, hirsuto na base, margens e ápice; estilete 1,8-2,7 mm compr. Frutos sub-orbiculares, raro oblíquos, comprimidos lateralmente, 1,5-2,4×1,4-2,2 cm, estipitado, base arredondada, ápice arredondado; semente 1(2) oblongo-globosa, 1,2-1,3×0,8$0,9 \mathrm{~cm}$, arilo branco.

Material selecionado: BRASIL. MARANHÃO: Alcântara, 28.IX.1903, fr., A. Ducke s.n. (MG 442, RB); Caxias, 28.VI.1907, fr., A. Ducke s.n. (MG 713, RB). PARÁ: Belterra, praia de Porto Novo, 29.X.1947, fr., G. A. Black 47-1845 (IAN); Belém, ilha do Mosqueiro, propriedade do Murça Pires, 12.VI.1979, fl., J. H. Langenheim \& M. F. Silva 6490 (INPA).

Ocorre apenas no Brasil, na porção oriental da Amazônia brasileira; foi encontrada amplamente distribuída no Pará indo até ao Maranhão (Fig. 4). Habita as matas de terra firme e várzea, matas de transição, capoeiras, campos, campinaranas e até mesmo dunas.

Ducke (1915) referiu-se à C. martii ocorrendo da Guiana até o Mato Grosso e que no nordeste do Brasil, ocorreria C. rigida Benth. Esse autor comentou que a última espécie citada, provavelmente, seria uma forma de C. martii com folíolos mais rígidos, devido ao clima seco. Ducke (1925) reafirmou suas suspeitas a respeito da proximidade de $C$. martii e $C$. rigida. Mais tarde, esse mesmo autor (Ducke 1930) reduziu C. rigida à variedade de $C$. martii, explicando que se tratava de uma variedade exclusiva de área de clima seco no nordeste brasileiro, diferindo, dessa maneira, da variedade típica que habita a Amazônia.

Dwyer (1951) propôs C. rigida como sinônimo de C. martii. Não obstante, Ducke (1958) reduziu $C$. martii e $C$. rigida a sinônimos de C. coriacea (Mart.) Hayne e comentou que a espécie ocorre desde o Pará até o Rio Grande do Norte e o interior da Bahia. Posteriormente, durante estudos botânicos no Ceará, Ducke (1959) reafirmou as sinonímias propostas, e comentou ainda que discordava de Bentham (1870) quanto à proposta de sinonimizar $C$. coriacea e $C$. cordifolia Hayne, e que a área de ocorrência de $C$. coriacea vai do Pará ao Rio Grande do Norte. É importante ressaltar que a referida proposta de Bentham (1870) havia sido aceita por Dwyer (1951). 

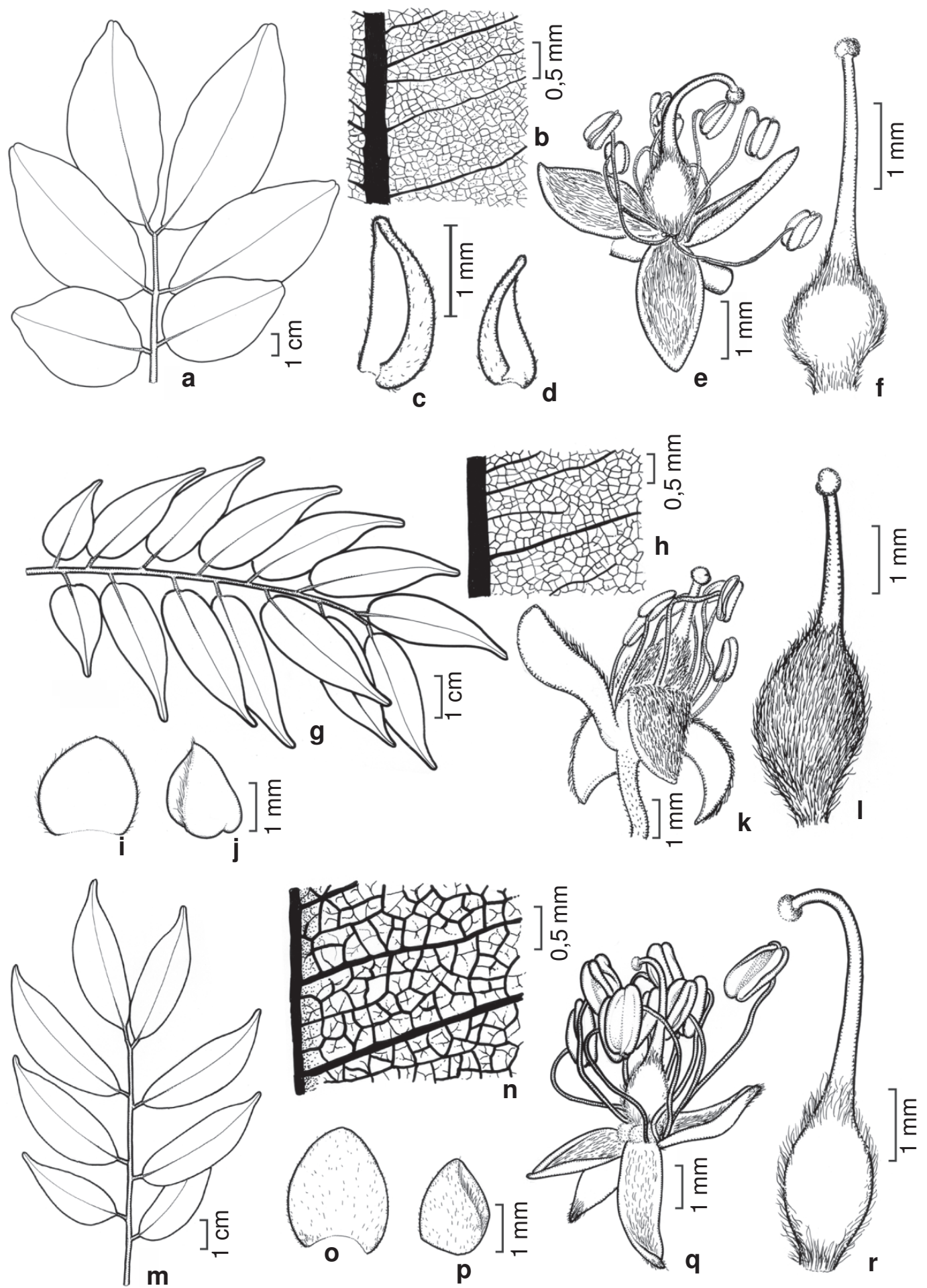

Figura 2 - a-f. Copaifera martii - a. folha; b. detalhe do folíolo evidenciando venação congesta; c. bráctea; d. bractéola; e. flor; f. gineceu. g-l. C. multijuga - g. folha; h. detalhe do folíolo evidenciando venação congesta; i. bráctea; j. bractéola; k. flor; l. gineceu. m-r. C. paupera - m. folha; n. detalhe do folíolo evidenciando venação congesta; o. bráctea; p. bractéola; q. flor; r. gineceu. (a Martins-da-Silva 116; b Martins-da-Silva 117; c-f Pires 4249; g, i-1 Martins-da-Silva 133; h Martins-da-Silva 129; m, o-r Rigamonte-Azevedo 3; n Martins-da-Silva 177) 
Embora seja necessário examinar os síntipos de $C$. rigida para confirmar a sua inclusão como sinônimo de $C$. martii, os materiais identificados por Ducke (1915) como C. rigida foram aqui considerados $C$. martii.

Quando se compara o tipo de $C$. martii (Pará) com um dos sintipos de C. rigida (Gardner 2089), procedente do Piauí, parece se tratar, realmente, de dois táxons diferentes. Apesar das flores semelhantes, os folíolos são diferentes: na primeira, apresentam ápice acuminado, menos coriáceos, glabros na nervura central na face abaxial e as margens são apenas levemente revolutas; enquanto que em C. rigida, os folíolos são brilhantes, com ápice amplamente obtuso e arredondado, mais coriáceos, glabrescentes na nervura central na face abaxial e ainda apresentam as margens revolutas. No entanto, quando se observam os materiais desde o oeste do Pará, procedentes dos municípios de Óbidos, Santarém e Belterra, no sentido do nordeste, nos municípios de Marapanim, Salinas e ilha do Marajó, bem como as amostras procedentes do Maranhão, torna-se difícil distinguir as duas espécies, devido à sobreposição desses caracteres vegetativos. No material procedente desses municípios citados, há folíolos oblongos, oblongosovados até orbiculares, algumas vezes os apicais mostram-se oblongo-obovados; os ápices podem ser obtusos ou agudos, os quais podem ser arredondados, retusos ou acuminados; em uma mesma amostra, encontram-se folíolos com diferentes formas.

Copaifera martii, quando ocorre em mata, desenvolve-se como árvore alta chegando a atingir até 40 metros de altura ou mais, os folíolos são menos coriáceos do que quando se desenvolvem em ambientes mais abertos, como os campos ou as areias de ambientes costeiros e até mesmo as capoeiras; contudo, o brilho dos folíolos, provavelmente, está ligado à fase de maturação desses órgãos que, quando mais jovens, são mais brilhantes; nas amostras desidratadas, os folíolos maduros, geralmente, apresentam-se glaucescentes.

Dwyer (1951) não teceu considerações sobre o Tipo da referida espécie. Hayne trabalhou na Universidade de Berlin e é possível que tenha examinado o material de Martius nesse herbário, destruído na Segunda Guerra Mundial. Como não houve indicação por Hayne (1827) do herbário, optou-se pela lectotipíficação do exemplar depositado por Martius em Munique (M).

5. Copaifera multijuga Hayne, Getreue Darstell. Gew. 10: pl. 17. 1827. Tipo: BRASIL. Wächst in lunern von Brasilien in den Wäldern der Provinzen Para und Rio Negro, s.d. (1819?), Martius s.n. (Lectótipo M!, aqui designado, fotos do lectótipo: F!, GH!, IAN!). Fig. 2 g-1 Árvore (5-7)15-60 m alt. e 6,5-118 cm DAP; às vezes sapopemas, ritidoma cinza a cinza-avermelhado, estrias estreitas verticais superficiais. Folhas com 6-10 pares de folíolos, pecíolo e raque pubescentes a hirsutos, pecíolos 0,5-2,5 cm compr., raque 6,8-20 cm compr.; estípulas interpeciolares caducas. Folíolos alternos, coriáceos, oblongo-lanceolados, falcados, assimétricos, base arredondada ou cuneada, subequilátera, ápice estreito-acuminado, atenuado à margem interna e abrupto à margem externa, falcado, os distais 2,1-6,6 $\times$ $0,9-2,7 \mathrm{~cm}$, os proximais $2-5 \times 0,8-2,4 \mathrm{~cm}$ e os medianos 3,2-7,4 × 1,1-2,8 cm, faces adaxial e abaxial glabras; margens retas; nervura central impressa na face adaxial ou semi-plana, pubescente a glabrescente, face abaxial hirsuta ou pubescente, com muitos ou raros tricomas; venação congesta (média 29,5 aréolas $/ \mathrm{mm}^{2}$ ), inconspícua adaxial; pontuações translúcidas distribuídas, preferencialmente, de forma homogênea em toda a lâmina; peciólulos pubescentes ou hirsutos $0,2-0,5 \mathrm{~cm}$ compr. Inflorescências com 5,1-12 cm compr; bráctea $2-2,6 \times 1,7-3 \mathrm{~mm}$, faces abaxial e adaxial glabras, tricomas nas margens; bractéolas 1,6-2,4 $\times$ 1,4-2,2 mm, faces abaxial e adaxial glabras, tricomas nas margens. Flores sésseis; sépalas externamente glabras, a mais larga 4-4,8 $\times$ 2,4-3 mm, as médias 4-4,8 $\times 1,6-2,4 \mathrm{~mm}$ e a mais estreita 4-4,8 $\times 0,9-2 \mathrm{~mm}$; anteras $2,3-$ 2,9 $\times 1-1,2 \mathrm{~mm}$; gineceu 5,6-7,7 mm compr., ovário oblongo a oblongo-elíptico, estipitado, 2,7-3,8 $\times 1,8-2,9 \mathrm{~mm}$, totalmente hirsuto; estilete 2,9-3,9 mm compr. Frutos suborbiculares, oblongo-obovados ou oblongo-oblíquos, 
comprimidos lateralmente, $3,7-4,6 \times 2,1-3,7 \mathrm{~cm}$, estipitado, base falcada ou subfalcada; semente 1, oblongo-globosa, nigrescente, 1,8-2,6 ×1$1,8 \mathrm{~cm}$, arilo amarelo.

Material selecionado: BRASIL. AMAZONAS: Manaus, BR 174, fundos da colônia João Alfredo, 26.VIII.1947, fr., A. Ducke 2101 (IAC, IAN, MG, R, UEC); margem do rio Tarumã, 3.III.2004, fl., R. C. V. Martins-da-Silva et al. 131 (IAN, INPA). MATO GROSSO: Aripuanã, 7.VI.1977, J. P. L. \& Damião C. 1816(INPA); 11.IV.1977, M. Gomes et al. 1164 (INPA). PARÁ: igarapé Santa Júlia, baixo Amazonas, 28.XII.1920, A. Ducke s.n. (RB 20209); Aveiro, rio Tapajós, 12.IX.1916, fr., A. Ducke s.n. (MG 16490, R, RB). RONDÔNIA: Costa Marques, BR 429, 30.III.1987, fr., C. A. C. Ferreira et al. 8734 (F, INPA, $\mathrm{K})$; Machadinho d' Oeste, Campo Experimental da Embrapa de Machadinho, 26.X.2004, R. C. V.Martinsda-Silva et al. 183 (IAN). BOLÍVIA. PANDO: S. bank of rio Abunã between cachoeira Tres S. and Fortaleza 3-16 km above mouth, 18.VII.1968, fr., G. T. Prance et al. 6138 (INPA, K, MG, MO, R); W. bank of rio Madeira, $3 \mathrm{~km}$ above Ribeirão, 27.VII.1968, fr., G. T. Prance et al. 6530 (INPA, K, MO).

Ocorre no Brasil e na Bolívia. NaAmazônia brasileira, vai desde a Amazônia central até o extremo ocidental, estendendo-se a sudoeste dessa região; foi encontrada no leste do Pará, amplamente distribuída no Amazonas, no norte e sul de Rondônia e a noroeste de Mato Grosso (Fig. 4). Típica de mata de terra firme, porém, pode ser encontrada em matas de várzea, e em campinarana.

Copaifera multijuga é bem definida morfologicamente por apresentar par distal de folíolos subopostos e demais alternos, total de seis ou mais pares, oblongo-lanceolados e assimétricos com ápice acuminado falcado, sendo atenuadamente acuminado na margem interna e abruptamente, na margem externa, formando uma curva bem pronunciada. Geralmente apresenta pontuações translúcidas perceptíveis à vista desarmada, distribuídas homogeneamente em toda a lâmina foliolar; a venação é inconspícua na face adaxial, a nervura principal é impressa ou ligeiramente plana; o ovário é totalmente coberto por tricomas; as anteras $(2,3-2,9 \times 1-1,2 \mathrm{~mm})$ e os frutos $(3,7-4,6 \times 2,1-3,7)$ são grandes em relação às outras espécies do gênero. Todos esses caracteres proporcionam distinguí-la das demais espécies do gênero ocorrentes na Amazônia brasileira.

$\mathrm{O}$ indumento presente no pecíolo, raque foliar, peciólulo e na nervura principal na face abaxial dos folíolos tem ampla variação, podendo apresentar-se densamente hirsuto, discretamente hirsuto, com raros e esparsos tricomas ou pubescentes.

Dwyer (1951) apenas menciona a foto do Tipo em (F), sem tecer maiores considerações. Da mesma forma que em C. martii, Hayne não indicou o herbário, em que estava depositado o material utilizado na descrição. Também se optou, como em C. martii, pela lectotipíficação do exemplar depositado por Martius em Munique (M).

6. Copaifera paupera (Herzog) Dwyer, Brittonia 7(3): 169. 1951. Tipo: BOLIVIA. SANTACRUZ: zerstreut im Urwald des Rio Blanco, besonders um die Laguna de Kaaupá (Prov. Velasco), IX.1909, fr., Herzog 470 (Lectótipo Z!, aqui designado; fotos da duplicata do lectótipo de B: F!, IAN!).

Fig. 2 m-r

Copaifera reticulata var. peruviana Macbride, Field Mus. Nat. Hist. 13(3): 120. 1943. Tipo: PERU. LORETO: Yurimaguas, X-XI.1929, Williams 4884 (Lectótipo F!, aqui designado; duplicatas do lectótipo A!, US!).

Árvore 20-35 (40) m alt. e 53-99(200) cm DAP; ritidoma apresentando desprendimento em placas pequenas ou grandes, cinza-rosado, cinzaavermelhado ou acastanhado. Folhas com 34(5) pares de folíolos, 5-10 cm compr., pecíolo e raque glabros, pecíolo $0,9-2 \mathrm{~cm}$ compr., raque 3,6-9 cm compr.; estípulas interpeciolares caducas. Folíolos alternos, cartáceos, oblongoovados estreitos, oblongo-obovados estreitos, oblongo-lanceolados, subfalcados a falcados, assimétricos, base arredondada ou cuneada, ápice curto a longo acuminado, podendo apresentar reduzido apículo, falcado, os distais 4-7,4 × 1,5$3 \mathrm{~cm}$, os proximais $3-5,9 \times 1,4-2,8 \mathrm{~cm}$ e os medianos 3,7-6,9 × 1,5-2,9 cm, faces adaxial e abaxial glabras, margens retas; nervura central adaxial impressa, glabra, abaxial glabra; venação 
congesta (média 21,7 aréolas $/ \mathrm{mm}^{2}$ ), inconspícua adaxial; pontuações translúcidas imperceptíveis à vista desarmada; peciólulos glabros, $(0,2) 0,3$ $(0,4) \mathrm{cm}$ compr. Inflorescências $10-15 \mathrm{~cm}$ compr.; bráctea 2,4-2,7×2,7-3 mm, face abaxial glabrescente, face adaxial glabra, tricomas nas margens; bractéolas 2,1-2,4×1,3-1,7 mm, abaxial glabrescentes, adaxial glabras, tricomas nas margens. Flores sésseis; sépalas externamente glabras, podendo apresentar discreto tufo de tricomas no ápice ou tricomas no ápice e na base, a mais larga 4-4,5 ×2-2,5 mm, as médias 4-4,5 $\times 1,7-1,9$ mm e a mais estreitas 4-4,5 $\times 1-1,7 \mathrm{~mm}$; anteras 1,6-1,9×0,9-1 mm; gineceu 4,7-6,1 mm compr., ovário oblongo a oblongo-elíptico, estipitado, 1,9-2,2×1,5-1,8 mm, hirsuto na sutura e nervura principal do carpelo, base e ápice; estilete 2,8-3,9 mm compr. Frutos sub-orbiculares, comprimidos lateralmente, $3,5-4,3 \times 2,2-3,1 \mathrm{~cm}$, estipitado, base arredondada, ápice arredondado ou truncado; semente oblongo-globosa, nigrescente, 1,7-1,9×1,3-1,4 cm, arilo amarelo. Material selecionado: BRASIL. ACRE: Assis Brasil, sentido Brasiléia, colônia às margens do rio Acre, 25.III.1999, fl., A. R. S. Oliveira 855 (RB); Bujari, BR 364 , km 52, colônia Nova Olinda, riozinho do Andirá, à esquerda descendo o rio, 15.V.1999, fr., G. Claros et al. 334 (IAN, RB). PERU. MADRE DE DIOS: Parque Nacional de Manu, Cocha Cashu Biological Station, 20.VIII.1976, fr., R. Foster \& C. Augspurger, 3277 (F). UCAYALI: Prov. Purus, rio Curanja, $10^{\circ}$ 04 S, $71^{\circ} 06$ W, 18.X.1997, J. Graham \& V. Schunke 197 (F, R); Pucalpa, Carretera Pucallpa-San Alejandro km 80, 29.II.1972, D. Simpson \& V. Schunke $64(\mathrm{~F})$.

Ocorre no Brasil, Bolívia e no Peru. $\mathrm{Na}$ Amazônia brasileira, encontra-se a sudoeste, restrita ao Acre, onde está amplamente distribuída (Fig. 4). Habita mata de terra firme.

Copaifera paupera é afim de $C$. reticulata, da qual difere pela inflorescência congesta, folíolos com nervura central impressa e venação congesta e inconspícua na face adaxial, com média de 21,7 aréolas por $\mathrm{mm}^{2}$. Outro caráter importante para distinção dessas espécies é a ausência de indumento no pecíolo, raque, peciólulo e nervura central dos folíolos em C. paupera.
Macbride (1943) propôs C. reticulata var. peruviana, distinguindo-a pela condição glabra dos folíolos e o legume subséssil, a qual foi proposta por Dwyer (1951) como sinônimo de C. paupera.

$\mathrm{O}$ ápice dos folíolos de $C$. paupera apresentou-se curto ou longo acuminado; quanto ao indumento externo nas sépalas, foram observadas sépalas totalmente glabras, glabras com tufo de tricomas no ápice e glabras com tricomas no ápice e na base. Considerando que as amostras disponíveis com flores maduras são poucas, há necessidade de coletar mais material fértil para otimizar a análise dessa variação.

Materiais procedentes de Rondônia (Cordeiro 481, 542; Goulding 1392; Prance 6760 e Rosa 446) e do Amazonas (Ducke s.n. RB 35416), esta última coletada ao sul do referido estado, mais precisamente, no município de Humaitá, ou seja, bem próximo de Rondônia, apresentam os caracteres morfológicos vegetativos afins com $C$. paupera, porém, discordaram pelos tricomas presentes na raque, pecíolos, peciólulos e na nervura central na face abaxial, caracteres esses que são encontrados em $C$. reticulata. Diante da presença desses tricomas e da ausência de flores nessas amostras, optou-se por considerá-las como afim de $C$. paupera, até que se obtenham flores de indivíduos dessas populações e se possa, então, tomar uma decisão mais segura quanto à posição taxonômica das mesmas.

7. Copaifera piresii Ducke, Bol. Técn. Inst. Agron. N. 36: 73-75. 1959. Tipo: BRASIL. PARÁ: Posto dos Índios Caiabi in campo aperto naturali prope flumen São Manuel (= Teles Pires) in civitatis Pará extremo austro-occidentali, 8.I.1952, fl., Pires, J.M. 3876 (Holótipo IAN!; isótipos INPA!, NY!).

Fig. 3 a-g

Arbusto ou árvore (1)10-35 m alt. e 40$80 \mathrm{~cm}$ DAP; ritidoma estriado superficialmente, cinza-rosado a avermelhado. Folhas com 4-7 pares de folíolos, pecíolo glabro, 0,2-0,5 cm compr., raque pubescente ou glabrescente, $1,8-6,9 \mathrm{~cm}$. compr.; estípulas interpeciolares persistentes. Folíolos opostos, raramente subopostos, cartáceos, distais oblongo-obovados, proximais e medianos 

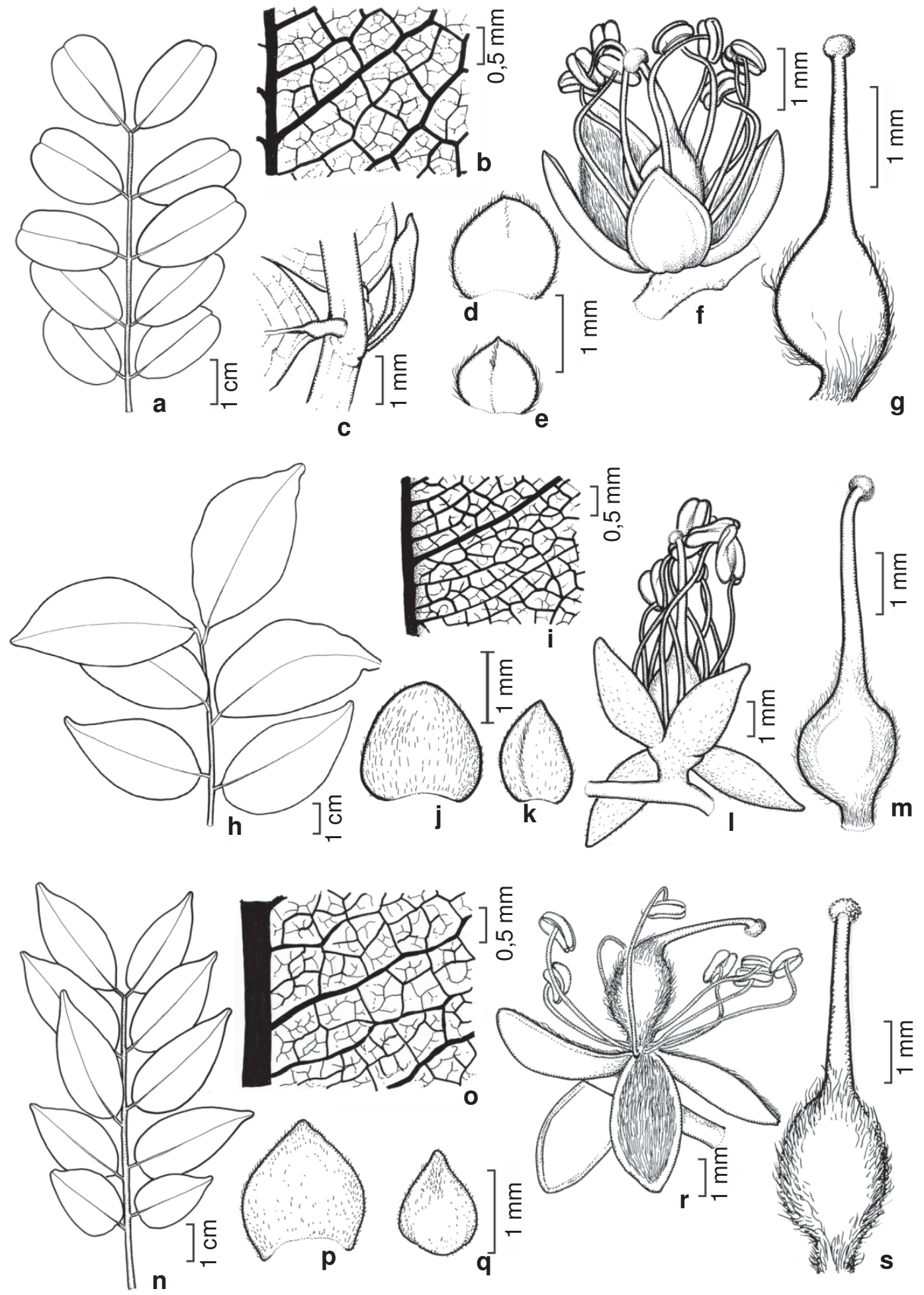

Figura 3 - a-g. Copaifera piresii - a. folha. b. detalhe do folíolo evidenciando venação laxa; c. detalhe da folha evidenciando estípula; d. bráctea; e. bractéola; f. flor; g. gineceu. h-m. C. pubiflora - h. folha; i. detalhe do folíolo evidenciando venação congesta; j. bráctea; k. bractéola; 1 . flor; m. gineceu. n-s. C. reticulata - n. folha; o. detalhe do folíolo evidenciando venação laxa; p. bráctea; q. bractéola; r. flor; s. gineceu. (a, c-g Egler 1185; b Pires 3876; h, j-m Martins-da-Silva 146; i Martins-da-Silva 155; n-o, r-s Pena 74; p-q Oliveira s.n. (IAN179.888)) 
oblongos, retos, geralmente simétricos, quando assimétricos apenas na base, base aguda equilátera no par distal, arredondada subequilátera a assimétrica nos pares proximais e medianos, ápice arredondado, retuso e mucronado, os distais $1,1-2,8 \times 0,66-1,4 \mathrm{~cm}$, os proximais $0,9-2 \times 0,5-1,1 \mathrm{~cm}$ e os medianos $1,1-2,5 \times 0,56-1,2 \mathrm{~cm}$, faces adaxial e abaxial glabras, margens retas; nervura central adaxial plana, glabra, abaxial glabra; venação laxa (11,4 aréolas $/ \mathrm{mm}^{2}$ ), conspícua adaxial; pontuações translúcidas quase sempre apresentando dificuldades para visualização; peciólulos glabros, $0,04-0,1 \mathrm{~cm}$ compr. Inflorescências $7-$ $10 \mathrm{~cm}$ compr.; bráctea $0,9-1,5 \times 0,8-1,4 \mathrm{~mm}$, glabra em ambas as faces, tricomas nas margens; bractéolas $0,7-1,2 \times 0,6-1,1 \mathrm{~mm}$, abaxial e abaxial glabras, tricomas nas margens. Flores sésseis; sépalas externamente glabras, podendo apresentar tufo de tricomas no ápice, a mais larga 2,6-3,3 × 1,8-2 mm, as médias 2,6-3,3× $1,4-1,7 \mathrm{~mm}$ e a mais estreita $2,6-3,3 \times 1-1,1$ $\mathrm{mm}$; anteras 0,9-1,4×0,4-0,8 mm; gineceu 2,9$4 \mathrm{~mm}$ compr., ovário orbicular a suborbicular, estipitado, 1,4-1,8 × 0,4-1,2 mm, hirsuto na sutura e nervura principal do carpelo, base e ápice, podendo ser glabro no ápice; estilete 1,52,2 mm compr. Frutos obovados ou oblíquos, comprimidos lateralmente, 1,5-2,7×1,5-2 cm, estipitado, base falcada ou subfalcada, ápice arredondado; semente oblongo-globosa, $1 \times$ $0,7 \mathrm{~cm}$, arilo amarelo.

Material selecionado: BRASIL. MATO GROSSO: beira do rio Juruena, 2.VII.1977, fr., M. G. Silva \& J. Maria 3256 (F, HAMAB, INPA, MG, RB); picadão que dá acesso do rio Juruena à pista do garimpo do mesmo nome, 13.VI.1977, fr., N.A. Rosa \& M. R. Santos 2119 (INPA, MG, RB). PARÁ: Altamira, cachoeira do rio Curuá, 23.V.2005, fr., J. B. F. Silva 1442 (IAN); Jacareacanga, alto Tapajós, rio Cururu, Missão Campo da Tábua, 13.VII.1958, fr., W. A. Egler 871 (IAN, MG). RONDÔNIA: Alvorada d'Oeste, BR 429, 29.IV.1987, fr., C. A. C. Ferreira 8946 (F, INPA, K); Presidente Médice, rodovia Alvorada-Presidente Médice, 21.VI.1983, fl., M. G. Silva 6300 (IAN, INPA, MG RB).

Ocorre apenas no Brasil, ao sul da Amazônia brasileira; foi encontrada no sudoeste do Pará, noroeste de Mato Grosso e a leste, oeste e centro-sul de Rondônia (Fig. 4). Parece ser uma espécie típica de campo cerrado, porém, foi encontrada em matas de terra firme e de várzea e em campinarana.

Ducke (1959) comentou que $C$. piresii difere de $C$. oblongifolia Mart. ex Hayne e de $C$. trapezifolia Hayne, pela ausência de pontuações translúcidas nos folíolos da primeira espécie. Examinando o tipo, realmente em alguns folíolos não se detectam essas pontuações; mas em outros, com auxílio de objeto de aumento e sob intensa luminosidade, é possível encontrálos, porém são menores e em menor quantidade do que nos observados em C. oblongifolia e em C. trapezifolia.

Copaifera piresii tem estreita afinidade morfológica com $C$. oblongifolia e $C$. trapezifolia, pois todas três possuem pecíolos e peciólulos curtos, folíolos pequenos, sendo de quatro a 10 pares e estípulas persistentes na base das folhas. A primeira espécie, geralmente, é arbusto ocorrendo nos campos cerrados do sul da Amazônia, mas também se faz presente em mata desse bioma com porte arbóreo; a segunda ocorre no cerrado do Brasil central como arbusto; a terceira é árvore e habita a mata atlântica.

Entretanto, C. piresii possui tanto caracteres de $C$. oblongifolia quanto de $C$. trapezifolia, ou seja, tem venação laxa e peciólulos glabros que são caracteres de $C$. trapezifolia, porém, a forma dos folíolos oblonga é afim com $C$. oblongifolia, apesar de apresentar, em algumas folhas, a base dos folíolos parecendo com C. trapezifolia com exceção dos folíolos basal e apical; os peciólulos são curtos como em $C$. oblongifolia, mas não chegam a ser séssil como em $C$. trapezifolia.

Outros caracteres que contribuíram para considerar $C$. piresii como táxon distinto de C. oblongifolia foram os ligados à morfologia polínica, pois Barata (2006) classificou o pólen dessas duas espécies em diferentes subtipos, C. piresii ficou no Subtipo Polínico paupera e C. oblongifolia, no Subtipo Polínico multijuga.

Dentre as espécies amazônicas, $C$. piresii se destaca pelos folíolos pequenos $(0,9-2,8 \times$ $0,5-1,4 \mathrm{~mm})$, de quatro a sete pares e estípulas permanentes. 
8. Copaifera pubiflora Benth., J. Bot. (Hooker). 2 (10): 101. 1840. Tipo: BRITISH GUIANA, 1840, fl., Schomburk 839 (Holótipo K!; isótipos F!, G!, NY!, OXF!, US!). $\quad$ Fig. 3 h-m

Copaifera martii var. pubiflora (Benth.) Benth., Fl. bras. 15 (2): 244. 1870.

Árvore 5-20 m alt. e 15-91 cm DAP; ritidoma soltando placas finas, cinza-amarelado a cinza-alaranjado. Folhas com (1)2-3 pares de folíolos, pecíolo e raque glabros ou glabrescentes, pecíolos glabros ou glabrescentes, 0,7-2,3 cm compr., raque $1,1-7,2 \mathrm{~cm}$ compr. Folíolos subopostos, cartáceos, ovado-elípticos ou ovado-oblongos, subfalcados, assimétricos, base obtusa assimétrica, ápice retuso e ligeiramente acuminado, os distais 2,3-8,5 × 1,9-4,5 cm, os proximais $2,2-6,7 \times 1,8-3,9 \mathrm{~cm}$ e os medianos $3,4-7,1 \times 2,4-4 \mathrm{~cm}$, faces adaxial e abaxial glabras, margens retas; nervura central adaxial plana, glabra, abaxial glabra; venação congesta (15,2 aréolas $/ \mathrm{mm}^{2}$ ), inconspícua adaxial; pontuações translúcidas quase sempre imperceptíveis; peciólulos glabros ou glabrescentes, $0,2-0,3 \mathrm{~cm}$ compr. Inflorescências 7-15 cm compr.; bráctea 1,2-2 × 1,2-2,1 mm, face abaxial pubescente, face adaxial glabra, tricomas nas margens; bractéolas $0,7-1,5 \times 0,6-1,4 \mathrm{~mm}$, face abaxial pubescente, face adaxial glabra, tricomas nas margens. Flores, subsésseis; sépalas externamente pubescentes, a mais larga 2,7-3,7×1,2-2,7 mm, as médias $2,7-3,7 \times 1-2,1 \mathrm{~mm}$ e a mais estreita 2,7-3,7 ×0,9-1,7 mm; anteras 1,3-1,9 ×0,40,92 mm; gineceu 3,8-6,1 mm compr., ovário orbicular a suborbicular, estipitado, 1,8-2,7×1,2$2,1 \mathrm{~mm}$, hirsuto na sutura e nervura principal do carpelo, base e ápice; estilete 2-3,4 mm compr. Frutos oblongo-obovados ou oblongo-oblíquos, comprimidos lateralmente, 2,3-3 × 1,4-2 cm, base arredondada, podendo também se apresentar ligeiramente atenuada, ápice arredondado ou mais raramente truncado; semente oblongoglobosa, 1,3-1,5×0,6-0,8 cm, arilo branco.

Material selecionado: BRASIL. RORAIMA: BR 174, 22.IX.2004, fl., R. C. V. Martins-da-Silva et al. 155 (IAN); fazenda São Bento, Capela Bom Intento, 3.IX.1951, fr., G. A. Black 51-13285(IAN). COLÔMBIA. CASANARE: Esmeralda, río Casanare, 19.X.1938, fl., J. Cuatrecasas 3858 (F). VICHADA: rio Meta,
Orucué, 16.X.1938, fr., J. Cuatrecasas 3715 (F); Parque Nacional Natural "El Tuparro", along rio Orinoco at Miramar, $5^{\circ} 10$ N, $67^{\circ} 50$ W, 3.V.1985, fr., J. L. Zarucchi \& C. E. Barbosa 3553 (INPA). GUIANA. UPPER TAKUTU-UPPER ESSEQUIBO: Marakanata, near Quatata, 19.IX.1931, fl., Forest Department 2182 (FHO, K); Rupununi District, Kuyuwini Landing, Kuyuwini River, 12.X.1992, fr., M. J. Jansen-Jacobs et al. 2871 (CAY, F, K). VENEZUELA. AMAZONAS: Puerto Ayacucho, $1 \mathrm{~km}$ east of Hotel Amazonas, 12.XI.1953, fl., B. Maguire et al. 36179 (IAN, VEN). APURE: entre río Arauca y Cunaviche, 23.IV.1977, N. Xena 50 (INPA, RB). BOLÍVAR: rio Paraguaza, on western slopes of Cerro Marimarota 5 km, 4.I.1956, fr., J. J Wurdack \& J. V. Monachino 41106 (F, IAN, K, RB). COJEDES: Cerros de El Baúl, I.1985, fr., M. Ramia \& R. Ortiz 8472 (VEN). GUÁRICO: Calabozo, Estacion Biológica Calabazo, XI.1965, fl., L. Aristeguieta 5943 (VEN). PORTUGUESA: detras de los Terrenos de La Unellez, 11.XI.1983, fl., G Aymard \& N. Solorzano 2219(VEN).

Ocorre no Brasil, Colômbia, Guiana e na Venezuela. Espécie com ampla distribuição no norte da América do Sul, sendo encontrada desde a região dos cursos superiores das bacias dos rios Takutu e Essequibo na Guiana, estendendo-se pelo Planalto Guianense até o sopé das cordilheiras dos Andes na Colômbia. Na Amazônia brasileira, só foi coletada no extremo norte, no estado de Roraima, onde está amplamente distribuída (Fig. 4). Habita várzeas e savanas, podendo também ser encontrada em matas de terra firme.

Bentham (1870) considerou C. pubiflora como uma variedade de $C$. martii, diferindo-a da variedade típica pelo cálice pubescente em ambas as faces e o ápice acuminado dos folíolos, mais evidente.

Dwyer (1951) restabeleceu C. pubiflora e indicou C. martii var. pubiflora Benth. como sinônimo dessa espécie. Segundo esse autor, além das áreas de ocorrência encontradas neste estudo, C. pubiflora ocorreria também nos estados do Amazonas e Ceará. Em relação ao Amazonas, houve uma certa confusão, pois julgou o lugarejo de São Marcos, próximo ao rio Branco, no município de Boa Vista, como pertencente ao Amazonas, quando na verdade pertence ao estado de Roraima. Para ocorrência no Ceará, o autor se baseou na coleta Gardner 
839 (F). Porém, é provável que a referida amostra tenha tido sua etiqueta trocada por engano durante o processo de preparação da exsicata, sendo uma duplicata de Schomburgk 839; na etiqueta dessa amostra (F 1025191) há o nome de Gardner, com referência ao local (Ceará) e data da coleta (1838) impressos; porém o número 839 está escrito à caneta em uma etiqueta improvisada e colado ao lado da etiqueta convencional. Como esse material é muito parecido com o exemplar tipo de $C$. pubiflora (Schomburgk 839), do qual existe uma duplicata no herbário $F$ (533414), supõe-se que a amostra e o número 839 seja de Schomburk, e a etiqueta de Gardner tenha sido colada por engano. Essa hipótese é reforçada pela existência do holótipo de C. pubiflora (Schomburgk 839) depositado no herbário K, cuja numeração encontra-se em uma etiqueta improvisada separada da etiqueta, sendo a tinta e a grafia do número 839 similares ao da amostra do herbário F (1025191).

Morfologicamente, $C$. pubiflora é mais afim de $C$. officinalis (Jacq.) L. e C. venezuelana Pittier \& Harms do que de C. martii, visto que a última tem folíolos opostos, coriáceos, margens semi-revolutas, enquanto as outras apresentam folíolos subopostos ou alternos, cartáceos e margens retas.

Quanto à C. pubiflora e C. officinalis, podem ser separadas pela primeira possuir folíolos com reticulação inconspícua na face adaxial, pontuações translúcidas imperceptíveis à vista desarmada (em raras amostras consegue-se visualizá-las com auxílio de objeto de aumento e sob intensa luz, porém, em pouca quantidade e não distribuídas homogeneamente na lâmina). As sépalas pubescentes na face abaxial e o ovário hirsuto em ambas as margens são caracteres de $C$. pubiflora que reforçam sua distinção de C. officinalis; esta possui folíolos com reticulação conspícua, pontuações translúcidas perceptíveis à vista desarmada $\mathrm{e}$ distribuídas homogeneamente na lâmina, sépalas glabras na face abaxial e ovário com tricomas apenas na face dorsal.

Copaifera pubiflora e C. venezuelana separam-se pela primeira ter folhas com 2-3 jugas e reticulação congesta e inconspícua, na face adaxial; enquanto que $C$. venezuelana tem quatro a cinco jugas e reticulação conspícua na face adaxial e menos congesta.

Ducke (1959) comentou que os espécimes, que coletou em Roraima, na mata marginal do rio Branco, foram considerados em trabalhos anteriores, como $C$. officinalis baseado em Bentham (1870), que julgava $C$. bijuga idêntica à $C$. officinalis, porém, no referido trabalho, Ducke assumiu que essas amostras são de C. bijuga, visto que, segundo ele, coincidem com a prancha desse táxon apresentada por Hayne (1827).

$\mathrm{Na}$ descrição de Hayne (1827) e na referida estampa de C. bijuga, observam-se dois pares de folíolos opostos, enquanto que os espécimes que Ducke coletou em Roraima têm folíolos alternos ou subopostos; na amostra Ducke 1361 há dois e três pares de folíolos, não podendo, dessa forma, ser identificada como $C$. bijuga. A análise do tipo de $C$. bijuga (herbário B 08359) revelou que a mesma foi coletada na Bahia.

Os espécimes coletados em Roraima possuem tronco com casca pulverulenta, outras vezes, papirácea soltando-se como papel parecendo espécies de Myrtaceae e até mesmo soltando-se em placas; a coloração é muito vistosa, indo de um cinza bem discreto, com predominância do amarelo e chegando até um tom alaranjado forte. A coloração amarelo-alaranjada parece predominar no tronco dos indivíduos que habitam áreas mais abertas, enquanto a cinza começa a aparecer mais nos indivíduos que se encontram em áreas um pouco mais fechadas. Logo após a deiscência do fruto, o arilo se mostava branco, depois tornando-se alaranjado ainda na árvore. A coloração alaranjada tornava-se mais forte à medida que $\mathrm{o}$ arilo vai se desidratando ou, provavelmente, se oxidando.

A venação de $C$. pubiflora, apresenta-se congesta com média de 15,2 aréolas por mm² $^{2}$ e terminações livres, curvas e bifurcadas.

As coletas Ducke 1370 (F 1485694; IAN 10821; MG 17918 e R 54774), Luetzelburg 20401 (R 69043) e 20403 (R 66478) exibem caracteres entre $C$. pubiflora e $C$. officinalis, pois possuem 
reticulação dos folíolos um pouco mais conspícua do que de $C$. pubiflora, mas não tão evidentes quanto à de $C$. officinalis; algumas sépalas são externamente glabras, outras com alguns raros e esparsos tricomas distribuídos ao longo dessa estrutura. Porém, não se conseguiu encontrar, nesse material, caracteres suficientes que justifiquem um novo táxon; podendo até se pensar nas considerações de Enrech et al. (1983) quanto à possibilidade de hibridização entre C. pubiflora e C. officinalis.

9. Copaifera reticulata Ducke, Arch. Jard. Bot. Rio de Janeiro 1: 22. 1915. Tipo: BRASIL. PARÁ: inter stationes Breu Branco et Arapary viae ferreae super vicum Alcobaça ad fluvium Tocantins, 2.I.1915, fl., Ducke s.n. (Lectótipo MG 15603!, aqui designado; duplicatas do lectótipo F!, RB!, US!; fotos do lectótipo: F!, IAN!).

Fig. 3 n-s

Árvore (15)30-40(60) m alt. e (16)40 70(98) cm DAP; podendo apresentar discretas sapopemas, ritidoma estriado, cinza-rosado. Folhas com 4-6 pares de folíolos, pecíolo e raque pubescentes ou glabrescentes, pecíolos 0,6-2 cm compr., raque 6-12,3 cm compr. Folíolos alternos ou subopostos, cartáceos, raramente coriáceos, oblongos ou ovadoelípticos, falcados a subfalcados, assimétricos, base obtusa subequilátera, raramente cuneada, ápice acuminado, podendo apresentar apículo, os distais 3,3-6,2 $\times 1,1-2,5 \mathrm{~cm}$, os proximais 2 $4,4 \times 1,7-2,7 \mathrm{~cm}$ e os medianos $2,9-6,1 \times 1,1-$ $2,3 \mathrm{~cm}$, faces abaxial e adaxial glabras, margens retas; nervura central ambas as faces proeminente, pubescente ou glabrescente; venação laxa (média 9,3 aréolas $\left./ \mathrm{mm}^{2}\right)$, conspícua na face adaxial; pontuações translúcidas geralmente presentes; peciólulos pubescentes ou glabrescentes, 0,2 $0,8 \mathrm{~cm}$ compr. Inflorescências com $6-15 \mathrm{~cm}$ compr.; bráctea 1,8-2,2×1,7-2,1 mm, face abaxial glabrescente e adaxial glabra, tricomas nas margens; bractéolas 1,3-1,6×1-1,3 mm, face abaxial glabrescente e adaxial glabra, tricomas nas margens. Flores subsésseis; sépalas externamente glabrescentes ou glabras, a mais larga 3,3-4x 2,4-2,8 mm, as médias 3,3-4×1,5-2 $\mathrm{mm}$ e a mais estreita 3,3-4×1,3-1,7 mm; anteras 1,2-
1,6×0,6-0,9 mm; gineceu 3,9-5,8 mm compr., ovário oblongo-elíptico, estipitado, 1,9-2,5×1,3$1,8 \mathrm{~mm}$, hirsuto na sutura e nervura principal do carpelo, ápice e base; estilete 2-3,3 mm compr. Frutos obovados, sub-orbiculares, podendo apresentar-se oblíquos, comprimidos lateralmente, $2,3-3,7 \times 1,5-3,5 \mathrm{~cm}$, base falcada ou subfalcada, ápice arredondado; semente com ca. 1,7-2 $\times$ 1-1,4 cm, arilo amarelo-alaranjado.

Material selecionado: BRASIL. AMAPÁ: Mazagão, BR 156, comunidade do Breu, 2.XII.2003, R. C. V. Martins-da-Silva et al. 118 (HAMAB, IAN); Porto Grande, Contagem entre Porto Platon e serra do Navio, 15.XII.1976, N. A. Rosa 1389 (MG). MATO GROSSO: Aripuanã, Núcleo de Aripuanã, 1.IV.1977, M. Gomes \& C. D. A. Mota 1131 (INPA). PARÁ: in silvis terrae altae ad flumen Cuminá-mirim (Trombetas), 13.X.1913, Ducke s.n. (síntipos MG! 14974, F!; foto do síntipo MG: F!); rio Tapajós, 29.XII.1917, fl., $A$. Ducke s.n. (MG 16854); Almerim, Monte Dourado, Jarí Celulose, 18.X.2001, fr., D. S. Pena 63 (IAN, JARI); RORAIMA: Caroebe, Entre Rios, 15.I.1983, I. A. Rodrigues et al. 989 (IAN).

Ocorre apenas no Brasil, na Amazônia brasileira, foi encontrada amplamente distribuída na porção oriental, rara na ocidental e ausente a nordeste; amplamente distribuída no Pará, encontra-se, ainda, a sudoeste do Amapá, sudeste de Roraima e norte de Mato Grosso (Fig. 4). Habita mata de terra firme.

Copaifera reticulata é afim de C. duckei da qual se separa por possuir quatro a seis pares de folíolos oblongos ou oblongo-elípticos, raque da folha maior (6-12,3 cm compr.), sendo pubescente ou glabrescente; o pecíolo, peciólulo e nervura central em ambas as faces são pubescentes ou glabrescentes. As brácteas e bractéolas glabrescentes externamente, sépalas glabras ou glabrescentes externamente. O retículo formado pela venação na face adaxial dos folíolos, em C. reticulata apresenta-se menos conspícuo e brilhante, bem como as aréolas são ligeiramente menores do que em C. duckei, tendo sido encontrada uma média de 9,3 aréolas por mm².

Copaifera reticulata apresenta, também, afinidades com $C$. paupera, da qual difere pelos folíolos com nervura central proeminente e venação laxa e conspícua na face adaxial, com média de 9,3 aréolas por $\mathrm{mm}^{2}$. Outro caráter 


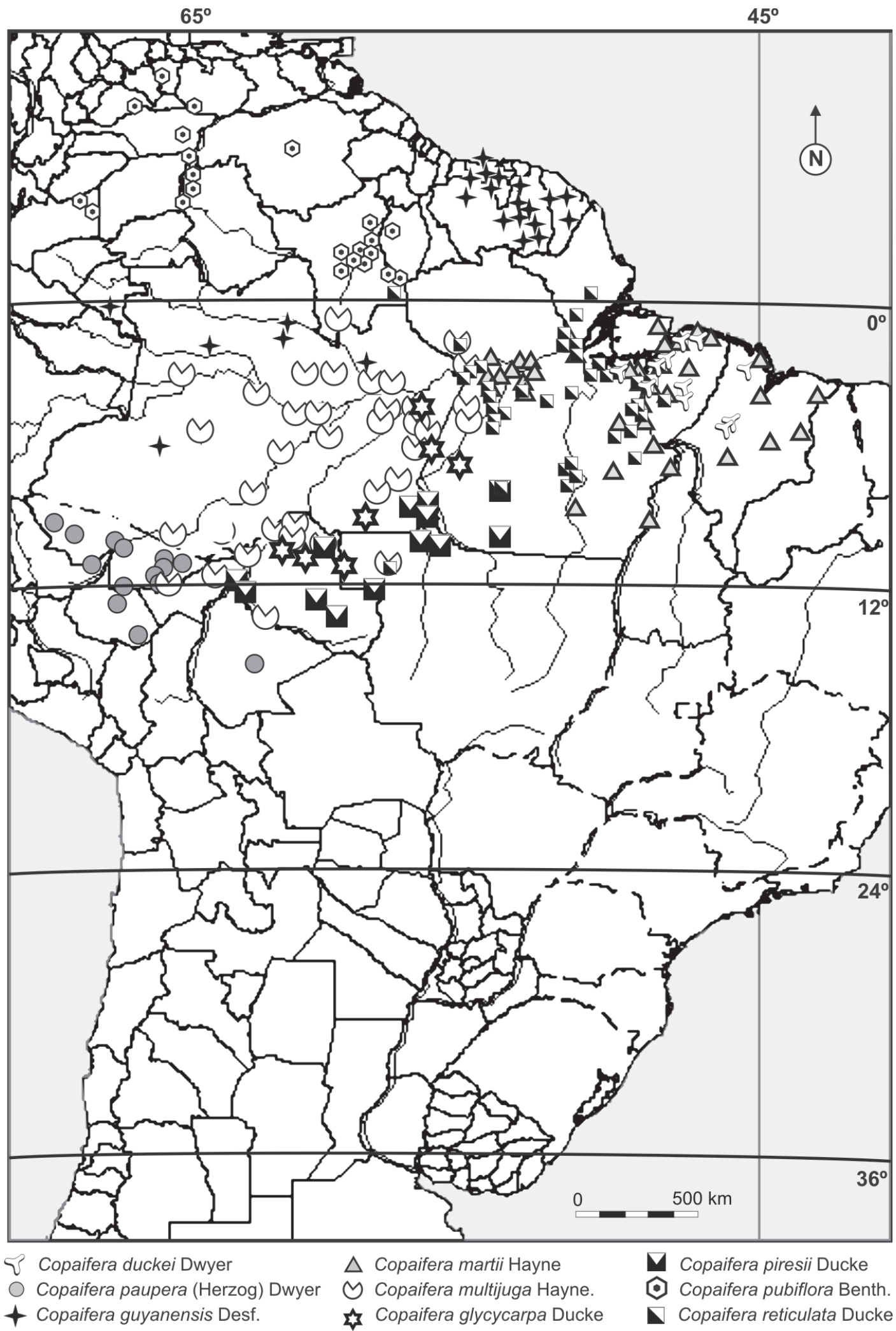

Figura 4 - Distribuição geográfica das espécies de Copaifera da Amazônia brasileira. 
importante para distinção dessas espécies é a presença de indumento no pecíolo, raque, peciólulo e na nervura central dos folíolos, que podem ser glabrescentes ou pubescentes em C. reticulata.

Macbride (1943) propôs C. reticulata var. peruviana Macbride que foi sinonimizada por Dwyer (1951) em C. paupera (Herzog) Dwyer.

De acordo com Dwyer (1951), C. reticulata ocorre em São Paulo, tendo citado, para esse estado, a coleta Riedel \& Lund 1805 (NY, US). Porém, ao examinar a duplicata dessa coleta (RB 84428) verificou-se que este material pertence à $C$. langsdorffii Desf.

Em algumas amostras de $C$. reticulata, observaram-se, nos folíolos, pequenas depressões circulares localizadas na porção central das aréolas. Essas estruturas são provavelmente glândulas que podem ser melhor observadas na face adaxial, podem, mais raramente, ser visíveis na face abaxial. Nas amostras provenientes dos municípios localizados mais a noroeste do Pará (Oriximiná e Óbidos) não se encontram tais elementos, detectados nos exemplares dos municípios vizinhos a esses, ou seja, Santarém e Belterra. Nos municípios de Juruti e Almerim e no Amapá, verificaram-se amostras com e sem as referidas estruturas. Nos exemplares dos municípios localizados mais ao sul do Pará, praticamente todas as amostras possuem tais depressões. É importante ressaltar que a quantidade dessas estruturas varia, podendo ter folíolos com todas as aréolas possuindo essas depressões ou com apenas uma ou duas depressões em toda a lâmina.

Dwyer (1951) descreveu C. langsdorffii var. krukovii Dwyer, sendo essa a única ocorrência dessa espécie na Amazônia, provavelmente, deve se tratar de uma variedade de $C$. reticulata, porém, no momento, necessita-se de estudos em $C$. langsdorffii que possam oferecer maiores esclarecimento quanto à posição da referida variedade.

Os materiais procedentes do Acre, depositados no herbário HPZ (RigamonteAzevedo, O.C. et al. 12, 19, 26; Oliveira, A.R.S. 851), dos municípios de Assis Brasil, Porto Valter e Tarauacá, possuem caracteres vegetativos próximos à $C$. reticulata, porém, como são estéreis, há necessidade de se coletar amostras férteis dessas populações a fim de se prosseguir as análises.

\section{Agradecimentos}

Os autores agradecem ao Projeto Dendrogene (Embrapa/DFID) pelo apoio financeiro, aos curadores dos herbários pelo empréstimo de exsicatas, aos Centros de Pesquisa da Embrapa localizados na Amazônia, ao INPA, IEPA, UFAC e à UFRR pelo apoio logístico durante os trabalhos de campo, aos coletores e demais integrantes das equipes de campo, ao Dr. Mike Hopkins pelas imagens digitais e a todos aqueles que direta ou indiretamente contribuíram para este trabalho.

\section{ReferênCIAS Bibliográficas}

Alencar, J. C. 1982. Estudos silviculturais de uma população natural de Copaifera multijuga Hayne - Leguminosae, na Amazônia Central. 2-Produção de óleoresina. Acta Amazônica 12(1): 75-89.

Arruda, M. B. (org.). 2001. Ecossistemas brasileiros. IBAMA, Brasília, 49p.

Barata, F. C. A. 2006. O pólen de Copaifera L. (Leg. Caes.) e suas implicações filogenéticas. Tese Doutorado, Universidade Federal do Amazonas/INPA, Manaus, 150p.

Bentham, G. 1870. Leguminosae II. Swartzieae et Caesalpinieae. In: Martius, C. F. P. von; Eicher, A.W. \& Urban, I. (eds.). Flora brasiliensis. Munchen, Wien, Leipzig, 15(2): 239-249.

Berg, M. E. van den. 1993. Plantas medicinais na Amazônia: contribuição ao seu conhecimento sistemático. MPEG, Belém, 207p.

Cascon, V.\& Gilbert, B. 2000. Characterization of the chemical composition of oleoresins of Copaifera guyanensis Desf., Copaifera duckei Dwyer and Copaifera multijuga Hayne. Phytochemistry 55(7): 773-778.

Corrêa, M. P. 1931. Dicionário das plantas úteis do Brasil, e das exóticas cultivadas. Vol. 2. Ministério da Agricultura, Rio de Janeiro, 707p. 
De Wit, H.C.D. 1953. Copaifera palustris (Symington) De Wit, comb. nov. Webbia 9(2): .462-463.

Ducke, A. 1915. Plantes nouvelles ou peu connues de la région amazonienne (I). Archivos do Jardim Botanico do Rio de Janeiro 1: 7-57.

. 1925. Plantes nouvelles ou peu connues de la région amazonienne (III). Archivos do Jardim Botanico do Rio de Janeiro 4: 45-47. 1930. Plantes nouvelles ou peu connues de la région amazonienne (IV). Archivos do Jardim Botanico do Rio de Janeiro 5: 127-129. 1958. Notas adicionais às leguminosas da Amazônia brasileira. Boletim Técnico do Instituto Agronômico do Norte 36: 73-74. 1959. Estudos botânicos no Ceará. Notas sobre sistemática. Anais da Academia Brasileira de Ciências 31(2): 291.

Dwyer, J. D. 1951. The Central American, West Indian and South American species of Copaifera (Caesalpiniacea). Brittonia 7(3): 143-172.

Enrech, X. N.; Arroyo, M. T. K. \& Langenheim, J. 1983. Sistemática del género Copaifera L. (Leguminosae: Caesalpinioideae, Detarieae) em Venezuela. Acta Botanica Venezuelica 14: 239-290.

Forero, E. 1983. Connaraceae. Flora Neotropica Monograph 36: 1-208.

Harris, J. G. \& Harris, M. W. 2001. Plant identification terminology: an illustrated glossary. $2^{\text {nd }}$ ed. Spring Lake Publishing, Utah, 216p.

Hayne, F. G. 1827. Getreue Darstellung und Beschreibung der in der Arzneykund gebräuchlichen Gewächse, wie auch solcher, welche mit ihnen verwechselt werden können. Auf. Kosten des Versfassers, Berlin, 10.

Hickey, M. \& King, C. 2003. The Cambridge illustrated glossary of botanical terms. Cambridge University Press, Cambridge, 208p.

Holmgren, P. K. \& Holmgren, N. H. 1998 onwards (continuously updated). Index
Herbariorum. New York Botanical Garden. Disponível: http://sciweb.nybg.org/ science2/IndexHerbariorum.asp. Acesso em: janeiro 2007.

Hou, D. 1994. Studies in Malesian Caesalpinioideae (Leguminosae). 1. The genera Acrocarpus, Afzelia, Copaifera and Instisia. Blumea 38: 313-330.

Johansen, D. A. 1940. Plant Microtecnique. 2.ed. Tata McGraw-Hill, Bombay, 532p.

Langenhein, J. H. 2003. Plant resins: chemistry, evolution, ecology and ethnobotany. Timber Press, Portland, 586p.

Lawrence, G. H. M. 1951. Taxonomia das plantas vasculares. Fundação Calouste Gulbenkian, Lisboa, v. 2.

Léonard, J. 1949. Notulae Systematicae IV (Caesalpiniaceae-Amherstieae africanae americanaeque), Bulletin du Jardin Botanique de l'Etat Bruxelles 19(4): 383407.

1950. Étude botanique des Copaliers du Congo Belge. Publications de l'Institut National pour L'Étude Agronomique du Congo Belge, série scientifique 45: 55-91.

Lewis, G. P. 1987. Legumes of Bahia. Royal Botanic Gardens, Kew, 369p.

Macbride, J. F. 1943. Flora of Peru: Leguminosae. The Field Museum of Natural History, Botanical Series 13(1): 120-121.

Maia, J. G.; Zoghbi, M. G. \& Andrade, E. H. 2001. Aroma de flores na Amazônia e seus óleos essenciais. MPEG, Belém, 230p.

Martins-da-Silva, R. C. V. 2006. Taxonomia das espécies de Copaifera L. (Leguminosae-Caesalpinioideae) ocorrentes na Amazônia brasileira. Tese de Doutorado. Museu Nacional/ Universidade Federal do Rio de Janeiro, Rio de Janeiro, 258p.

MMA. 2004. Biomas continentais. IBGE, Brasília. Disponível em: <http:// www.ibge.gov.br/>. Acesso em: maio. 2006.

Pires, J. M. \& Prance, G. T. 1985. The vegetation types of the Brazilian Amazon. In: Prance, G. T. \& Lovejoy, T. E. (eds.). 
Key Envirouments: Amazonia. Pergamon Press, Oxford, 109-145.

Poveda, L. J.; Zamora, N. \& Sánchez-Vindas, P. E. 1989. Una nueva especie de Copaifera L. (Caesalpiniaceae: Leguminosae) para Costa Rica. Brenesia 31:.117-120.

Quirk, J. T. 1983. Data for a computer-assisted wood identification system I; commercial legumes of tropical Asia and Australia. IAWA 4(2-3): 118-130.

Rizzini, C.T. 1971. Plantas novas ou pouco conhecidas do Brasil. Revista Brasileira de Biologia 31(2): 192.
Shanley, P.; Leite, A.; Alechandre, A. \& Azevedo, C. 2005. Copaíba. In Shanley, P. \& Medina, G. (eds.). Frutíferas e plantas úteis na vida amazônica. CIFOR/ Imazon, Belém, 300p.

Siqueira, G. C. L. (coord.). 1996. Produtos potenciais da Amazônia. Ed. Sebrae, Brasília, 97p.

Stearn, W. T. 1998. Botanical Latin. $4^{\text {th }}$ ed. David \& Charles, London, 565p.

Veiga Junior, V. F. \& Pinto, A. C. 2002. O gênero Copaifera L. Química Nova 25: 273-286. 